Bartın Üniversitesi

Eğitim Fakültesi Dergisi

Cilt 6, Sayı 2, s. 689-714, Haziran 2017 BARTIN - TÜRKIYE

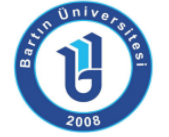

ISSN: 1308-7177
Bartin University

Journal of Faculty of Education

Volume 6, Issue 2, p. 689-714, June 2017

BARTIN - TURKEY

Doi: 10.14686/buefad.304498

\title{
Okul Yöneticilerinin Görüşleri Doğrultusunda Eğitim Finansmanı Politikaları: Sorunlar, Nedenler ve Çözümler
}

Esen ALTUNAY, Yrd. Doç. Dr., Ege Üniversitesi Eğitim Fakültesi, esenaltunay@yahoo.com

Öz: Araştırmanın amacı okul yöneticilerinin eğitim finansmanı politikalarına ilişkin görüşlerinin incelenmesidir. Araştırmada nitel araştırma desenlerinden olgubilim (fenomonoloji) deseni kullanılmıştır. Araştırmanın verileri yarı yapılandırılmış görüşme tekniği ile toplanmıştır. Çalışma grubunu ilkokul, ortaokul ve lise yöneticilerinden oluşan 30 katılımcı oluşturmaktadır. Araştırmada amaçlı örnekleme yöntemlerinden maksimum çeşitlilik örneklemesi ve verilerin toplanması için yarı yapılandırılmış görüşme formu kullanılmıştır. Araştırmanın verilerinin analizinde betimsel analiz ve içerik analizi yapılmıştır.Araştırmanın bulgularına göre okul yöneticileri okullarının giderlerinin karşılanması açııından okul yöneticilerinin taleplerine duyarsızlık gösterildiğini; eğitim finansmanı politikalarının uygulama sorunlarını okul temelli ve Bakanlık temelli sorunlar olduğunu; eğitim finansmanı politikalarının yansımalarının karşılaştırılması sonucu ilkokul ve ortaokul kademelerinin dezavantajlı olduğunu; politikalarının uygulama sorunlarının nedenleri olarak eğitim politikasının niteliği, bütçe yönetimi ve planlama eksikliğini belirtmişlerdir. Eğitim finansmanı politikalarına ilişkin görüşler doğrultusunda okul üyeleri ve yöneticileri ile bakanlık yöneticilerinin eğitim finansmanı yönetimi konusunda yetkinliklerinin güçlendirilmesi gerektiği söylenebilir.

lise

Anahtar Kelimeler: eğitim finansmanı, finansman politikaları, okul yöneticisi, ilkokul, ortaokul,

\section{Educational Financing Policies According to School Administrators' Views: Problems, Causes and Solutions}

Abstract: The purpose of research is to examine the school administrators' views about the education financing policies. The design of this research is conducted as phenomenological design among qualitative research design. In this research data were collected with the quasi-structured interview technique. The sample of this research composed of 30 school administrators from primarysecondary and high school administrators. In this research maximum variation sampling technique was used as one of the purposive sampling techniques. Descriptive and content analysis techniques were used to analyze the data of the study. According to the findings of this research, school administrators thought that the demands of school administrators were shown indifference in terms of meeting the expense of their schools. The implementation problems of educational financing policies were due to school-based and Ministry-based problems. When the reflections of education financing policies are compared, primary and secondary school levels are disadvantageous. The reasons for implementations problems are the quality of education financing policies, budget management and lack of planning. The competence of school members, administrators and ministry officials on education financing management needs to be strengthened.

Key Words: educational economy, education policy, school administrator, primary school, secondary school, high school 


\section{GíRiş}

Yaşam normlarını yükseltmek isteyen her toplumun temel amacı, sahip olduğu kaynakları öncelikleri doğrultusunda, en verimli ve etkili şekilde kullanarak üretim düzeyini en yükseğe çıkarmaktır (Tuzcu, 2004). İstenen verimlilik düzeyine erişebilmek teknoloji ve bilgi çağının getirdiği değişim adımlarını içeren "bilimsel planlama süreci"ni kapsayan politikalar ile mümkün olabilmektedir. İnsanların refah ve huzurunu sağlamaya yönelik uzlaştırıcı bir kimlik taşıyan politikalar toplumun tüm kaynaklarının birleşerek birbirine katkı sağlamasını mümkün kılabilmektedir. Bu anlamda ekonomik üretimin temeli olan eğitim politikaları geliştirilirken, toplumsal uzlaşma sağlanması, topluma eğitim politikalarının açıklanması ve toplumun ikna edilmesi önem taşımaktadır (Yapıcı, 2006).

Eğitim örgütü düzeyinde politikalar, eğitim hedeflerinin planlanan düzeyde gerçekleştirilmesini yöneten ilkeler ve kurallardır. Politikaları oluşturan kurallar ve ilkelerin örgüt üyelerinin görevlerini en iyi şekilde düzenlemesi beklenir. Kurallar gerçekleştirilecek eylemlerin yollarını, ilkeler ise örgütün çıktısına ilişkin temel fikirleri göstermektedir. Dolayısıyla politika örgütte yönetim tarafından alınacak kararlara ve atılacak adımlara yön vermektedir. Bu bağlamda eğitim politikasının amacı, eğitim örgütünün tutarlılık, kararlılık, süreklilik ve bütünlük içinde süreçlerini yürütmesini sağlamaktır (Özen, Gül ve Gülaçtı, 2007). Asında eğitim politikası ulusal bir proje gibidir çünkü geçmiş deneyimleri dikkate alarak güncel ihtiyaçlara çözümler bulması ve gelecekle ilgili beklentileri içermesi gerekir. Bu proje sürekli (sürdürülebilir), geliştirici, kararlı ve kapsayıcı olmalıdır (Yapıcı, 2006). Bu nedenle eğitim politikaları belirlenmesinde temel ölçüt bilimsellik olmalıdır.

Eğitim politikalarının çok kısa süreli olmaması; uzun vadeli ve istikrarlı olarak düzenlenmesi ve uygulanması gerekmektedir (Şimşek, 2016). Çünkü eğitim politikalarının etkileri uzun yıllar sonra görülebilmektedir. Eğitim politikası üreticilerinin, güncel olgu ve olaylardan hareketle etkisi yıllar sonra ortaya çıkabilecek kararları, yeterince irdeleyerek almaları gerekmektedir. Dolayısıyla bir eğitim yatırımının sonucunun ortalama 20-25 yılda ölçülebildiği düşünüldüğünde, eğitim politikasının belirleyicileri, almış oldukları yanlış kararların sonuçlarını görevde iken görememekte, çözüm üretmesi beklenmemekte ve hatta bir sorumluluk almamaktadır (Yapıcı, 2006). Bu nedenle eğitim politikalarının gelecek öngörüsü ile geliştirilmesi gerekmektedir. Bu bağlamda bir ülkedeki eğitim finansmanına ilişkin politikaların bu bağlam üzerinden değerlendirilmesi gerekmektedir.

Eğitimin finansmanı, toplumun eğitim talebinin karşılanması için gerekli mali kaynakların elde edilmesi sürecidir aynı zamanda kaynakların farklı sosyo-ekonomik düzeydeki gruplara ve bireylere, farklı eğitim kademeleri ve türleri, iller ve bölgelere dağılım süreci olarak tanımlanmaktadır. Belirtilen bu finansman türü kamu fonları, öğrenci harçları, eğitim materyalleri için yapılan harcamalar, özel fon vb. tarafından oluşmaktadır (Güngör ve Göksu, 2013). Eğitim finansmanına ilişkin politikalar ise bir ülkenin eğitim sisteminin hedeflerini gerçekleştirebilmesi ve varlığını sürdürebilmesi için gerekli olan kaynakların sağlanması ve harcamaların planlanması ve dağıtılması konusundaki yaklaşımlardır (Tonbul, 2016). Alanyazında eğitimin ekonomik rolüne göre eğitim finansmanı politikalarının oluşturulduğu görülmektedir. Davis'e (1980) göre eğitim planlaması araçları (yaklaşımları) incelendiğinde toplumsal talebin tahmin edilmesi, üretimin insangücü gereksinimleri planlaması (manpower forecasting approach), getiri oranları analizi, vb. sayılabilir. Üretimin insan gücü gereksinimleri yaklaşımı, eğitimi piyasanın istediği insan gücünü yetiştiren bir yatırım aracı olarak görür. Bu yatırımın sonunda insanda üretime dönük bilgi ve beceri kapasitesi gelişmekte, bu ise insanının kazancını geliştirmektedir (Tilak, 2002; Tonbul, 2016; Vila, 2005). Eğitim planlamasının görevi ekonomik ve toplumsal gelişmenin gerektirdiği işgücünü yetiştirmektir (Kurul, 2012). Diğer bir yaklaşım, sosyal istem yaklaşımıdır (social demand approach). Bu yaklaşım, eğitimi temel bir 
insan gereksinimi olarak görmektedir. Eğitim yaşamsal tüm gereksinimlerinin sağlanmasının önkoşuludur. Toplumu oluşturan tüm üyelerin eşit olanaklarla eğitim hizmetlerinden yararlanmasının sağlanması, yaşamları için gereksinimlerini karşılama kapasitesi geliştirilmesine çalışılır. Bu nedenle nitelikli eğitim sürecinden geçmiş bireyler daha sağlıklı olmakta, bu ise onların çalışabilme gücü kazanarak üretkenliğini artırmakta olup görece daha iyi gelir elde etmektedir (Tilak, 2002; Tonbul, 2016). Eğitimle insanın tüm yönleri ve kaynakların gelişimi gerekmektedir (Özdemir, 2011). Bir diğer yaklaşım ise getiri (verim) oranı (investment approach) yaklaşımıdır. Eğitim hizmetlerinin yaygınlaştırılması bir yatırım olarak değerlendirilir (Hesapçıoğlu, 1994; Kurul, 2012). Bu nedenle kaynakların dağıtımında maliyet ve yararların karşılaştırılması ve en yüksek oranda yarar sağlayacak olanın seçilmesi gerekmektedir (Aydın, 2000). Eğitim insana yapılan bir yatırımdır. İnsan sermayesi, bireyde üretime dönük bilgi ve becerilerin bütününü tanımlar. Alt yapı yatırımlarında olduğu gibi bireye yapılan yatırımların da bir getirisi ortaya çıkmaktadır. Bu getiri, bireyin üretimin bir parçası olduğu sürece elde ettiği kazançla belirlenmektedir. Getiri oranıysa bu kazançların tümünün, yatırımın maliyetine bölünmesiyle elde edilir. Eğitimin getiri oranı belli bir kademe eğitim görmüş bireylerle o kademede eğitim almamış olanların bütün yaşamındaki kazançlarıyla ve o kademe eğitiminin maliyetinin karşılaştırılması sonucu anlaşılır (Carnoy, 1995; Ergen, 2013; Tilak, 1977; Woodhall, 1974). Okullar ve eğitim gereksinimi dikkate alındığında günümüzde bu yaklaşımların hiçbiri tek başına yeterli görülmemektedir. Eğitim planlamasının sistemin içinde olması gerekmektedir (Eğitim planlarının esnek, çok yönlü, disiplinlerarası, işbirliği ile hazırlanmasını, bilimsel ve geçerli-güvenilir nesnel bilgi ve verilere dayalı olmasını gerektirmektedir (Tonbul, 2016). Bu değerlendirmeler ışığında Anayasa ve ilgili yasa, yönetmelikler, kalkınma planları ve milli eğitim şûralarının eğitimde finansman politikalarının temel dayanak noktalarını oluşturduğu söylenebilir. Bugüne kadar eğitim finansmanı politikalarına yol gösteren finansman kaynakları başta devlet gelirlerinin, il özel idare bütçeleri yıllık gelirlerinin, belediye gelirlerinin, yıllık köy bütçeleri gelirlerinin belli bir oranı, katkı payları ve harçlar krediler, vergiler vb. şeklinde sıralanabilir. Ayrıca 05.01.1961 tarih ve 222 sayılı ilköğretim ve Eğitim Yasası'nda, 14.06.1973 tarih ve 1739 sayılı Milli Eğitim Temel Yasası'nda, 05.06.1986 tarih ve 3308 sayılı Çıraklık ve Mesleki Eğitim Yasası'nda çeşitli finansal hükümler yer almaktadır (Kurul, 2012; Saklan ve Erginer, 2016). Bu anlamda eğitim planlamasında "insangücü yaklaşımı"nın öne çıktığı söylenebilir. "Ekonominin gereksinim duyduğu insangücünü yetiştirmek" ve "toplumun eğitim düzeyini yükseltmek" kalkınma planlarındaki eğitim programlarının iki hedefi olarak öne çıkmaktadır. Bu hedefler, Birinci Kalkınma Planı’ndan bu yana tüm kalkınma planlarında yer almaktadır. Bununla birlikte eğitim tür ve düzeylerine ve sistemin nitelik açısından düzenlenmesine ilişkin amaçlar ve politikalar, büyük oranda "insangücü yetiştirme" hedefine dönüktür. Ülkenin kalkınmasının araçlarından biri olarak eğitimin görülmesi, eğitimin işlevlerinde ağırlıklı olarak iktisadi işlevin öne çıkması, uzun dönemli nicel gelişmede meslekiteknik ortaöğretim ve yükseköğretime öncelik tanınması, kalkınma planlarındaki eğitim anlayışının ekonomik bir çerçevede görüldüğünü göstermektedir (Küçüker, 2010).

Dünyada eğitim finansmanı değerlendirilirken genel olarak üç farklı tür finansman yöntemi ile karşılaşılmaktadır. Eğitime kaynak sağlamada yaklaşımlarından ilki "doğrudan finansman yöntemi" eğitim harcamalarının kamu bütçesinden sağlandığı kamu finansmanı, yani vergilendirme anlayışıdır. Devlet, eğitim kaynaklarını tam kamusal mallarda olduğu gibi vergilerle karşılamaktadır. İkinci anlayış ise "dolaylı (özel) finansman yöntemi" eğitimde parasal kaynakların öğrencilerin ailelerinden finanse edilmesidir. Eğitim malının vergi yerine harçlarla karşılanmasıdır. Üçüncüsü de, "karma finansman yöntemi" eğitimden yararlanan her kesimin doğrudan veya dolaylı olarak kaynak sağlanmasına dayanan "kısmi finansman" yaklaşımıdır. Eğitim kaynakları kamu ve özel sektör tarafından finanse edilmektedir. Devlet eğitim malını arz ederken, özel sektöre de bu konuda ayrıcalık tanımakta ve bir anlamda eğitimin özelleştirilmesi 
sağlanmaktadır (Devrim ve Tosuner, 1987; Güngör ve Göksu, 2013; Kurul Tural, 2002; Tonbul, 2016). Türkiye'de eğitim harcamalarının yapısı incelendiğinde, toplam eğitim harcamalarının \% 37 si gibi çok önemli bir kısmı özel girişim tarafından gerçekleştirilmektedir. Oysa OECD ortalamasında, toplam eğitim harcamalarının yalnızca \% 12'si özel kaynaklar tarafından yapılmaktadır. Türkiye' de kamu tarafından yapılan eğitim harcamaları da OECD ortalamasından geride seyretmektedir (ERG, 2009). Buna göre eğitim planlaması ve finansman yönetiminin merkeziyetçi yapıda olduğu ve pratikte yerelleşme politikaları uygulandığı görülmektedir (Karakul, 2014). Kalkınma planları doğrultusunda eğitim programlarının mali politikalarının gelişimi çoğunlukla zorunlu eğitimin devlet tarafından finanse edilmesi, diğer eğitim düzeylerinde eğitimden yararlananların harcamalara katılması, eğitim harcamalarında olabildiğince tasarruf yapılması, eğitime ayrılacak kaynakların genel bütçe dışı fonlarla artırılması ve eğitim hizmeti sunumunda özel girişimin payının artırılmasını içeren benzer bir anlayış çerçevesinde devam etmektedir (Küçüker, 2010). Bir ülkede eğitim finansmanı modellerinden hangisinin uygulanacağı dikkate alınan eğitim politikası ve planlaması yaklaşımına göre değişebilmektedir. Türkiye'de eğitimde karma finansman anlayışı sonucu eğitime devletin yanı sıra, özel sektör, gönüllü kuruluşlar ve yararlananlar mâli katkı sağlamaktadırlar (Karakul, 2014). Hali hazırda genel bütçeden ve özel sektörden kaynak aktarıldığı için okullar finansal yönetimleri konusunda sınırlı özerkliğe sahiptirler. Okulların finansmanı bir önceki yılın okul bütçesindeki artışa dayalı şekilde belirlenmektedir. Mevcut durum dikkate alındığında personel ödemeleri ve bunun dışında sağlanması gereken kaynakların öğrenci sayısındaki artışla oranlı olarak sağlanamaması okulların gereksinimlerini karşılamakta güçlüğe düşmesine neden olmaktadır. Dolayısıyla ek donanım gereksinimleri okul aile birlikleri aracılığıyla velilerden elde edilen katkılarla giderilmeye çalışılmakta veya ortaöğretim mesleki ve teknik okulları da farklı faaliyetlerle temin etmeye uğraşmaktadır (OECD, 2013). Eğitimin finanse edilmesinde Temel Eğitime Destek Projesi, Ortaöğretime Destek Projesi, Mesleki Eğitimi Geliştirme Projesi vb. projeler ile uluslararası kuruluşlardan, sivil toplum kuruluşlarından ve özel sektörden projelerin amaçları doğrultusunda da eğitime kaynak ayrılmaya çalışılmaktadır (Karakul, 2014; Kurul, 2012; Şişman, 2014). Öte yandan planlı kalkınma politikası çerçevesinde eğitimin, toplumsal değişmeye katkı sunan bir "sektör" olarak görülmesi doğrultusunda eğitim planlaması çalışmaları, bir yandan ekonomik ve toplumsal gelişmenin gerektirdiği görevleri yerine getirmek için gerekli kaynakların sağlanmasına, diğer yandan da bu kaynakların eğitim sisteminin kademe ve türleri arasındaki dağılımına yoğunlaşmıştır (Küçüker, 2010). Ancak Türkiye'de okullarda mali kaynaklar bakımından bölgeler ve okullar arası oluşan farklar nedeniyle öğrencilerin öğrenme fırsatlarının olumsuz etkilendiği görülmektedir. Özetle bir ülkenin eğitim sisteminin amaçlarına ulaşabilmesi için gerekli ve yeterli eğitim ortamlarının sağlanması gerekmektedir. Nitelikli koşulların sağlanması eğitim ve finansmanı politikalarının belirleyicilerinin ve devleti yönetenlerin uygun politikaların belirlenmesi ile oluşmaktadır. Bu bağlamda okulların sınırlı olan kaynakları ile bütçe yönetimini gerçekleştirmeye çalışan okul yöneticileri ciddi zorluklarla baş etmek durumunda kalmaktadırlar. Bu anlamda eğitim kurumlarındaki finansman temelli yaşanan sorunların belirlenmesi, okul temelli önlemlerin alınması ve çözümler geliştirilmesi önem taşımaktadır.

Alanyazın incelendiğinde eğitim finansmanı ölçütlerinin ülkelerin insani gelişmişlik göstergelerinden olduğu özellikle 20. yüzyılın sonu ve 21. yüzyılın başından itibaren önem kazanan insani gelişme anlayışının temel bir değişkeni haline geldiği görülmektedir (Karakul, 2014). Gelişmiş ülkelerle karşılaştıııldığında Türkiye'de okullar temelinde bu ölçütler beklentileri karşılamaktan uzak kalmaktadır. Bu anlamda genelde eğitim politikaları ve özelde eğitim finansmanı politikaları alanında bilimsel araştırma sonuçlarının ve kaynakların artması gerek politika yapıcılara gerekse uygulayıcılara bir öngörü geliştirmeleri için fırsat sunabilmektedir. Eğitim, devlet ve birey açısından en büyük ve belki de en önemli kamu 
politikası girişimi olarak kabul edilmesine rağmen, Türkiye'de genelde eğitim politikaları, özelde eğitim finansmanı politikaları bağlamında üretilen çalışmaların sayısı sınırlıdır. Araştırmacıların eğitim finansmanı politikalarını sınırlı oranda çalışmasının birçok nedeni bulunmaktadır. Bireylerin politika konusu bir çatışma unsuru olarak algılaması ve bu nedenle veri toplama sürecini karmaşık duruma getirmesi veya okul yöneticilerin genelde eğitim politikası ve özelde eğitim finansmanı politikaları alanında edilgen bırakılmaları sonucunda bir süre sonra kabul etme eğilimini göstermesi ve çözüm üretmekten vazgeçmesi bu nedenle arasında sayılabilir. Buna rağmen eğitim kurumlarını ilgilendiren politikalardaki her değişiklik eğitim sisteminin en küçük birimi olan okulları ve bu okullarda çalışan yöneticileri ve öğretmenleri olumlu ya da olumsuz anlamda etkileyebilmektedir (Altunay ve Ağaçdiken, 2016). Üstelik okul yöneticileri eğitim kurumlarını ilgilendiren değişimlerin doğrudan uygulayıcısı, sonuçlarından etkilenen temel unsuru olabilmektedirler. Bu nedenle bu araştırmada okul yöneticilerinin eğitim finansmanı politikalarına ilişkin görüşlerinin incelenmesiyle alana katkıda bulunulması umulmaktadır.

\section{YÖNTEM}

$\mathrm{Bu}$ araştırmada okul yöneticilerinin eğitim finansmanı politikaları konusundaki görüşlerinin derinlemesine incelenebilmesi amacıyla nitel araştırma desenlerinden olgubilim (fenomonoloji) deseni kullanılmıştır. Yıldırım ve Şimşek'e (2013) göre olgubilim deseni olguyu yaşayan ve bu olguyu dışa vurabilecek veya yansıtabilecek bireyler ya da grupları veri kaynağı olarak alan araştırmacının farkında olduğu halde derinlemesine ve ayrıntılı bir anlayışa sahip olmasını istediği olguları incelemesini içeren araştırma desenidir.

\section{1. Çalışma Grubu}

Araştırmanın çalışma grubunu ilkokul, ortaokul ve lise yöneticilerinden oluşan 30 katılımcı oluşturmaktadır. Araştırmada amaçlı örnekleme yöntemlerinden maksimum çeşitlilik örneklemesi kullanılmıştır. Çalışma grubunun maksimum çeşitlilik göstermesini sağlamak amacıyla belirlenen katılımcılar üç kademedeki (ilkokul, ortaokul ve genel lise-meslek lisesi) eğitim kurumundan seçilen okul yöneticilerinden oluşmaktadır. Araştırmanın amacına uygun bir şekilde İzmir genelinde ilkokul, ortaokul ve liselerde çalışan okul yöneticilerinden eğitim finansmanına yönelik politikalarla ilişkili görüşleri istenmiştir. Çalışma grubunun çeşitli özelliklerine göre dağı̆ımları Tablo 1'de verilmiştir.

Tablo 1

Çalışma Grubunun Özellikleri

\begin{tabular}{llll}
\hline & Değişkenler & $\mathbf{n}$ & $\mathbf{\%}$ \\
\hline Cinsiyet & Kadın & 4 & 13,33 \\
Okul kademesi & Erkek & 26 & 86,67 \\
& ilkokul & 10 & 33,33 \\
& Ortaokul & 10 & 33,33 \\
Yöneticilikteki kıdem & Genel Lise ve Meslek Lisesi & 10 & 33,33 \\
& $1-5$ yıl & 8 & 26,67 \\
& $6-10$ yıl & 3 & 10 \\
Yaş & $11-15$ yıl & 5 & 16,66 \\
& $16-20$ yıl & 11 & 36,67 \\
Toplam & 21 yıl ve üstü & 3 & 10 \\
& $30-39$ yaş & 10 & 33,33 \\
& $40-49$ yaş & 6 & 20 \\
& 50 yaş ve üstü & 14 & 46,67 \\
\hline
\end{tabular}

Tablo 1'e göre katılımcıların çoğunluğu erkek $(n=26, \% 86,67)$, genellikle $16-20$ yıl ( $n=11, \% 36,670)$ veya $1-5$ yıl yöneticilik kıdemine sahip $(n=8, \% 26,67)$ ve yaşının 50 yaş ve üstü 
( $n=14, \% 46,67)$ veya $30-39$ yaş $(n=10, \% 33,33)$ aralığında olduğu ve okul kademelerine göre görülmektedir.

\subsection{Araştırmanın Veri Toplama Aracı}

Araştırmada nitel araştırma desenlerinden olgubilim araştırması deseninin seçilmesi nedeniyle verilerin toplanması için yarı yapılandırılmış görüşme formu kullanılmıştır. Yarı yapılandırılmış görüşme formu iki bölümden oluşmaktadır. Formun ilk bölümünde yöneticilerin kişisel özelikleri sorulmuş ikinci bölümünde eğitim finansmanı politikalarına ilişkin görüşleri istenmiştir. Araştırmada veri toplama aracı olarak geliştirilen formun uzman görüşleri doğrultusunda gerekli düzeltmeler yapılarak son şekli verilmiştir.

Araştırma verilerinin çeşitliliğini sağlamak adına özellikle farklı kademelerde çalışan okul yöneticilerinden görüşler toplanılmıştır. Araştırmada toplanan verilerin geçerliliği ve güvenilirliğini artırmak için teyit görüşmesi yapılmıştır. Görüşülen okul yöneticilerinin tümü transkrib (çeviriyazı) edilen bilgilerin kendi görüşleri olduğunu doğrulamıştır. Formlar ile toplanan veriler yazılı dokümanlar haline getirilmiştir.

\subsection{Araştırmanın Verilerinin Analizi}

Araştırmanın verilerinin analizinde betimsel analiz ve içerik analizi kullanılmıştır. Nitel desenlerde iki tür analiz tercih edilmektedir. Betimsel analiz, alt problemler doğrultusunda bulguların özetlenmesidir (Yıldırım ve Şimşek, 2004). İçerik analizi üç etkinlik basamağı (verilerin azaltılması, verilerin sunumu, sonuç çıkarma ve doğrulama) (Türnüklü, 2000) çerçevesinde verilerin önce kodlarının belirlenmesi, daha sonra temaların oluşturulması, kategorileştirme ve en son adımda alt problemlerle bu kategorilerin ilişkilendirilmesini temel almaktadır. Bu doğrultuda betimsel analiz için analiz öncesi alt problemler ve alanyazın doğrultusunda kategori listesi belirlenmiştir. Analize başlarken bu kategoriler dikkate alınarak veriler gruplara atanmıştır. İçerik analizi için anılardan toplanan veriler, ilk olarak kodlanmış, alt temalar oluşturulmuştur.

Betimsel analiz ve içerik analizi doğrultusunda ana temalar, alt kategoriler, ana kategoriler ve kodlar birbirleriyle ilişkilendirilmiş ve birleştirilmiştir. Veriler analiz edildikten sonra, alıntı seçimi için çarpıcılık (farklı görüş), açıklayıcılık (temaya uygunluk), çeşitlilik ve uç örnekler ölçütleri dikkate alınarak sunulmuştur. Araştırma verilerinin analizi sonucunda ortaya çıkan kategoriler ve alt kategoriler Tablo 2'de görülmektedir.

Tablo 2.

Verilerin Analizi Sonucu Ortaya Çıkan Kategoriler ve Alt Kategoriler

\begin{tabular}{lll}
\hline Alt Problemler & Kategoriler & Alt Kategoriler \\
\hline $\begin{array}{l}\text { Okul Yöneticilerine Göre } \\
\text { Finansman Kaynaklarının } \\
\text { Dağıımı }\end{array}$ & Okulun Gelirleri & Kamu kaynakları \\
& Okulun Giderleri & Özel kaynaklar \\
& & Fiziksel ortam giderleri \\
& Hizmet alımı giderleri \\
\hline $\begin{array}{l}\text { Eğitim Finansmanı } \\
\text { Politikalarının Uygulama } \\
\text { Sorunları }\end{array}$ & Okul temelli sorunlar & Eğitim gideri \\
& & Personele giderlerine ilişkin \\
& & sorunlar \\
& & Bütçenin yönetimine ilişkin \\
& Bakanlık temelli sorunlar & sorunlar \\
& & Eğitim giderinin karşılanmaması \\
& Bütçenin kısıtlı olması \\
& & Bütçe yönetiminde uzmanlaşma \\
& sorunları \\
\hline
\end{tabular}




\begin{tabular}{|c|c|c|}
\hline \multirow{4}{*}{$\begin{array}{l}\text { Okul Kademelerine Göre } \\
\text { Eğitim Finansmanı } \\
\text { Politikalarııın } \\
\text { Yansımalarının } \\
\text { Karşılaştııılması }\end{array}$} & İlkokulların finansmanı & Finansman Avantajı \\
\hline & Ortaokulların finansmanı & Finansman Avantajı \\
\hline & Liselerin finansmanı & Finansman Avantajı \\
\hline & & Finansman Dezavantajı \\
\hline \multirow{4}{*}{$\begin{array}{l}\text { Eğitim Finansmanı } \\
\text { Politikalarının Uygulama } \\
\text { Sorunlarının Nedenleri }\end{array}$} & Eğitim politikasının niteliği & \\
\hline & Planlama Eksikliği & \\
\hline & Veliden destek görememe & \\
\hline & Bütçe yönetiminde yetersizlik & \\
\hline \multirow{4}{*}{$\begin{array}{l}\text { Eğitim Finansmanı } \\
\text { Politikalarının } \\
\text { Sorunlarına Iliş̧kin } \\
\text { Çözüm Önerileri }\end{array}$} & Yeni eğitim finansmanı politikası & \\
\hline & Yönetim yapısı & \\
\hline & Finansman uzmanlık bilgisi geliştirme & \\
\hline & Kaynak kullanımı & \\
\hline
\end{tabular}

Tablo 2'de görüldüğü gibi, verilerin analizi sonucunda birinci alt problem doğrultusunda "Okul Yöneticilerine Göre Finansman Kaynaklarının Dağılımı" başlığı altında "Okulun Gelirleri ve Okulun Giderleri" olmak üzere iki ana kategori ortaya çıkmıştır. İkinci alt problem doğrultusunda "Eğitim Finansmanı Politikalarının Uygulama Sorunları" başlığı altında "Okul temelli sorunlar ve Bakanlık temelli sorunlar" şeklinde iki kategori vardır. Üçüncü alt problem doğrultusunda "Okul Kademelerine Göre Eğitim Finansmanı Politikalarının Yansımalarının Karşılaştırılması" başlığı altında "ilkokulların finansmanı, Ortaokulların finansmanı ve Liselerin finansmanı" olarak üç kategori söz konusudur. Dördüncü alt problem olan "Eğitim Finansmanı Politikalarının Uygulama Sorunlarının Nedenleri" başlığı altında ise "Eğitim politikasının niteliği, Planlama Eksikliği, Veliden destek görememe ve Bütçe yönetiminde yetersizlik" olarak dört kategori ortaya çıkmıştır. Beşinci alt problem doğrultusunda "Eğitim Finansmanı Politikalarının Sorunlarına ilişskin Çözüm Önerileri " başlığı altında ise "Yeni eğitim finansmanı politikası, Yönetim yapısı, Finansman uzmanlık bilgisi geliştirme ve Kaynak kullanımı" olarak dört kategori şekillenmiştir. İçerik analizinde temalar temel birimlerdir. Temalar bir araya gelerek bütüne (kategorilere) ulaşılmaktadır. Temalar görüşlerde yer alan temel kavramların (kodlar) bir araya gelmesi ile oluşur Tablo 2'de görüldüğü üzere bir kategorinin altında birçok alt kategori vardır. Bu araştırmada belirlenen kategori, alt kategori ve temalar bulgular bölümünde daha ayrıntılı olarak ele alınmaktadır.

Araştırmada nitel veri toplama sürecinin iç geçerliği (inandırıcılık) katılımcı teyidi, uzman incelemesi ve yapılan görüşmelerin sürelerinin uzun tutulması ile; dış geçerlik (aktarılabilirlik) araştırma süreci ve bu süreçte yapılan işlemler ayrıntılı bir şekilde ayrıntılı betimlenmesi ile sağlanmaya çalışılmıştır. İç güvenirlik için tutarlık incelemesi, dış güvenirlik (teyit edilebilirlik) için üç uzman tarafından gerçekleştirilen teyit incelemesi yapılmıştır. Araştırmacının konumu, elde edilen verilerin analizinde kullanılan kavramsal çerçeve, araştırmada veri kaynağı olan katılımcılar ve analiz yöntemleri ile ilgili ayrıntılı açıklamalara yer verilmiştir. Buna ek olarak gelecekte başka bir araştırmada karşılaştırmalar yapmak amacı ile ya da diğer araştırmacıların talep etmesi söz konusu olursa araştırmanın ham verileri saklanarak da dış güvenirlik artırılmaya çalışı Imıştır.Yapılan analiz sonucu elde edilen kodlar ve oluşturulan temaların etkili bir biçimde organize edilip edilmediğinin incelenmesi için oluşturulan kodlar ve temalar dört uzmanın görüşüne sunulmuştur. Görüşme dokümanlarından elde edilen bulguların sunumunda, katılımcıların görüşlerindeki önemli noktaları etkili bir şekilde yansıtabilmek amacıyla yer yer doğrudan alıntılara yer verilmiş (Yıldııım ve Şimşek, 2004) ve verilerin azaltılması, verilerin sunumu ve sonuç çıkarma-doğrulama etkinlik basamakları çerçevesinde (Türnüklü, 2000) paylaşılmıştır. 
Bulgular verilerin analizi sonucunda oluşan kategorilerin dağılımı temel alınarak sunulmuştur. Öncelikle bir ana kategoride katılımcıların görüşlerinin en çok yoğunlaştığı alt kategori daha sonra da bu kategorideki en yüksek sayılı tema ve alıntılar; ardından ikinci olarak gelen ana kategori ve ilgili temalar ve alıntılar verilmiştir. Böylece tablolardaki kategori ve tema sayıları sistematik olarak aktarılmaya çalışımıştır.

\section{BULGULAR}

Bu araştırmada katılımcıların görüşleri gizlilik esasına dayanılarak isimler verilmeden bir rakam ve çalıştığı okul kademesinin (ilkokul, ortaokul, lise veya meslek lisesi) ilk harfleri ile kodlanıp (IOM1, OM1, LM1, MLM1,...) aktarılmıştır.

\subsection{Okul Yöneticilerine Göre Finansman Kaynaklarının Dağılımı}

Araştırmanın birinci alt problemi "Okul yöneticilerinin eğitim finansmanı kaynaklarının dağılımına ilişkin görüşleri nelerdir?" şeklindedir. Okul yöneticilerinin finansman kaynaklarına ilişkin görüşlerinin incelemesi neticesinde iki kategori ortaya çıkmıştır: okulun gelirleri ve okulun giderleri. Okulun gelirleri kategorisinde "kamu ve özel" alt kategorileri belirlenmiştir. Okulun gelirleri kategorisinde "fiziksel ortam, hizmet alımı ve eğitim giderleri alt kategorileri belirlenmiştir. Okul yöneticilerinin görüşlerinin dağılımı Tablo 3 'te verilmiştir.

Tablo 3

Okul Yöneticilerine Göre Eğitim Finansmanı Kaynaklarının Dağılımı

\begin{tabular}{|c|c|c|c|c|}
\hline Kategoriler & Alt Kategoriler & Temalar & $\mathbf{n}$ & $\%$ \\
\hline Okulun & Kamu kaynakları & İnternet, elektrik, yakıt, su ve telefon ödemesi & 20 & 9,52 \\
\hline \multirow[t]{12}{*}{ Gelirleri } & & Kantin kirası geliri & 16 & 7,61 \\
\hline & & Genel Bütçe Onarım ödeneği & 10 & 4,76 \\
\hline & & İl ve İlçe MEM katkı payı & 8 & 3,82 \\
\hline & & Anasınıfı geliri & 5 & 2,38 \\
\hline & & Fotokopi çekim geliri & 4 & 1,91 \\
\hline & Özel kaynaklar & Veli bağışı & 14 & 6,66 \\
\hline & & Hayırsever bağışları & 12 & 5,71 \\
\hline & & $\begin{array}{l}\text { Sosyal etkinlik gelirleri (sinema, tiyatro, kermes } \\
\text { geliri) }\end{array}$ & 8 & 3,82 \\
\hline & & Okul alanlarının kira geliri & 8 & 3,82 \\
\hline & & Yerel yönetimden elde edilen gelir & 5 & 2,38 \\
\hline & & Proje geliri-bireysel kaynak yaratma & 4 & 1,91 \\
\hline & & Döner sermaye geliri & 4 & 1,91 \\
\hline Okulun & Fiziksel ortam & Bina bakım gideri & 16 & 7,62 \\
\hline \multirow[t]{8}{*}{ Giderleri } & gideri & Temizlik malzemesi & 14 & 6,66 \\
\hline & & Sigorta & 8 & 3,82 \\
\hline & & Araç-gereç bakım ücreti & 6 & 2,85 \\
\hline & & Demirbaş alımları & 6 & 2,85 \\
\hline & $\begin{array}{l}\text { Hizmet alımı } \\
\text { gideri }\end{array}$ & & 20 & 9,52 \\
\hline & Eğitim gideri & Kırtasiye tüketim gideri & 11 & 5,24 \\
\hline & & Eğitim-öğretim gideri & 6 & 2,85 \\
\hline & & Ders araçları & 5 & 2,38 \\
\hline Toplam & & & 210 & 100 \\
\hline
\end{tabular}

göstermekte bir katılımcı birden çok görüş belirtmektedir. Okul yöneticilerinin görüşlerinin okulun finansman kaynaklarının dağılımına göre yapılan ilk değerlendirmede okulun gelirleri ve okulun giderleri kategorileri oluşturulmuştur. "Okulun gelirleri" kategorisinde "kamu ve özel 
kaynaklar" alt kategorileri ortaya çıkmış, kamu kaynaklarına ilişkin en fazla "Internet, elektrik, yakıt, su ve telefon ödemeleri" $(n=20)$ ve ikinci olarak "kantin kirası geliri" $(n=16)$; özel kaynaklara ilişkin olarak en fazla "veli bağışı" $(n=14)$ teması öne çıkmıştır. Okul yöneticileri okullarının finansman kaynaklarının dağılımında gelir ve gider dengesini sağlamakta zorlandıklarını ve giderlerinin gelirlerini karşılamadığını belirtmişlerdir. Aynı zamanda gelirlerinin birinci sırada devlet tarafından karşılanması gerektiğini düşünmektedirler.Okul yöneticileri tarafından "İnternet, elektrik, yakıt, su ve telefon ödemeleri" temasına ilişkin vurgulanan bir alıntı şöyledir:

"Elektrik, su, telefon ve internet yaklaşık 1000-1500 liralık kullandığımız için faturalarını sisteme taratıyoruz. Bedeli ne ise gönderiyorlar, o konuda sıkıntı yok. MEBBis sistemini kullanıyoruz taradıktan sonra KBS (kamu bilgi sistemi) içerisine ödeneğimiz geliyor, yani örneğin bu ay 2000 lira elektrik 1900 lira elektrik faturamı vardı. iki gün içerisinde üst sistemden onaylandıktan sonra ödeneğimizi maliye onaylıyor. Fatura bedelini ödemek üzere 1950 lira bütçemize aktarılıyor." LM2

Okul yöneticilerinin görüşlerinde katılımcıların okulun gelirleri kategorisinde kamu gelirleri alt kategorisi "kantin kirası" temasında toplanabilecek benzer ifadeleri vardır. Bu temaya göre katılımcılar tarafından vurgulanan bir alıntı ise şöyledir;

\footnotetext{
"Okulların gelirlerden biri kantin gelirleridir. Okulların ortalama olarak aylık 3000-5000TL civarındadır. Öğrenci sayısına göre değişebilir. 5-6-7-8 sınıflara göre farklı olur. Bizim kantinin geliri aylık 1000 TL oluyor. Ancak bu gelir okulumuzun ihtiyaçlarının 1/3 karşılayabiliyor. Kantin geliri 9 ay boyunca ödenir. Ama şubatta tatil zamanında yarım kira ödeniyor. "OM1
}

Okul yöneticilerinin görüşlerinde katılımcıların okulun gelirleri kategorisinde özel kaynaklar alt kategorisi "veli bağışı" teması okul aile birliğine veliler tarafından yapılan bağışları, sınırıı̆̆ını ve sosyoekonomik çevreye göre değiştiğini içermektedir. Katılımcılardan bazılarının görüşleri veli bağışı ile ilgilidir. Katılımcılardan birinin veli bağışı konusuna örnek olabilecek bir alıntısı şöyledir:

"Birinci gelir kaynağımız velinin bağışıdır. Okul aile birliği talep ediyor. Veli isterse veriyor, istemezse vermiyor. Medyada olumsuz haberler bağış miktarını azaltıyor. Velilerin bağış yapması için okulda gelişmeleri görmesi, size inanması ve hizmet görmesine bağı, yoksa bağış yapmıyorlar. Biz onu başardık. Bu sayede okulun çatısını onardık." iOM2.

"Okulun giderleri" ana kategorisinde "fiziksel ortam giderleri" ve "eğitim-öğretim gideri" alt kategorileri ile "hizmet alımı gideri" teması ortaya çıkmakta; hizmet alımı gideri $(n=20)$ teması çoğu yönetici için ciddi bir gider olarak görülmekte, fiziksel ortama ilişkin en fazla "bina bakım gideri" ( $n=16)$ kategorisi öne çıkmaktadır. "Eğitim-öğretim gideri" alt kategorisinde kırtasiye tüketim gideri teması en çok vurgulanan tema olmuştur $(n=11)$. Okul yöneticileri okulun giderleri kategorisinde fiziksel ortam $(n=6)$ alt kategorisinde "bina -bakım gideri" temasında benzer ifadeleri içerecek görüşler belirtmişlerdir. Bu alt kategoriye göre katılımcılar tarafından vurgulanan iki alıntı ise şöyledir;

\begin{abstract}
"Genel bütçeden onarım istediğiniz zaman önce ilçede daha sonra ilde değerlendirilir. Genel onarıma 50-60 okul başvuruyorsa ancak 5 tanesi bu yıl şansa sahip olabilir. Bizim gibi 40 yılık bir okul boyanacaksa çok ciddi masraf oluyor. Yeni bir bina yapmaktan daha fazla tutuyor. Kalorifer sistemi değişmesi gerekliydi. Ama müdür olarak sürece dahil edilmiyorsun. Firma ile hukuki süreç yürüyor. Geçen yıl sadece okul aile birliğinin yardımıyla kendi bulduğumuz öz kaynaklarla motorunu değiştirmiştik. "MLM4
\end{abstract}

"Okul wc lerinin bakımı, panjurlar gibi küçük onarımları yeni yaptırdım. Bizde çocuklar kuzey ülkelerindeki gibi sakin değil. Akdeniz ülkesi insanı olarak biraz daha canlıyız. 8. Sınıflardan çok başarılı bir oğlan çocuğu derste elindeki gönye ile duvarı delmişti.... Her yıl boya yaptırtıyorum. Normal ihaleye çıksam 50 bin TL derler. Her yıl çamurlu duvarları, top izleri olan yerleri rötuş yaptıriyorum." OM3

"Binanın bakımıyla ilgili (senelik çatı, binayı boyatmak) gerekiyor. Sen kaynak yaratırsan var, yoksa yok. Bakım ve onarım diğer gider kalemleri, mesela kornişler yerinden çıkıyor, cam kitaplıklar 
kırılıyor. Elektrik tesisatı gidiyor. Kamera, ses düzeni, alarm var. Elektrikler gidip geldiği zaman otomatikman binadaki çoğu lambaları patlıyor. Elektriğin voltajının yükse-düşük olması aylık 2000 lira zarar çıkartır. Illkokulda 16 ve ana sınıfında 4 tane dersliğim var, toplam 20 dersliğim var, ister istemez boya yapmak zorundasın. Çünkü duvarlar patlıyor." iOM1.

Okul yöneticilerinin görüşlerinde okulun giderleri kategorisinde eğitim-öğretim gideri alt kategorisi eğitim amaçlı etkinlik gideri, mesleki gelişim gideri, ders araçları giderleri ve kırtasiye giderlerini içermektedir. Bu alt kategoride en çok "kırtasiye tüketim gideri" teması vurgulanmıştır. Bu tema katılımcılar ile fotokopi, toner parası, kağıt, karne, vb. tüketim malzemelerine harcadıkları giderleri ve bunlarla ilgili karşılaştıkları sorunları belirtmişlerdir. Kırtasiye tüketim gideri" temasına ilişkin katılımcılar tarafından belirtilen bazı alıntılar ise şöyledir;

"Kırtasiye gideri öğrenci ödülleri, kitaplar, plaketler, vb. minimum 7 TL.Kağıt ihtiyacı, fotokopi ihtiyacı olduğu zaman, belli periyotlarda ilçe milli eğitim müdürlüğünden alınabilir ama o da dişinin kabuğuna yetmiyor." iOM6.

"Eğitim-öğretim hizmetleri için ayrılan bir ödenek yok. Ancak kırtasiye ihtiyacı, toner ihtiyacı, fotokopi ihtiyacı şeklinde yani malzemelerin talebi yapılabiliyor. Genel bütçeden geldiği için öncelik alanlarına göre dağıtılarak geliyor. Kimi yıl geliyor, kimi yıl gelmiyor. Bu konu okulların çoğu için sorun. Bu alan gerçekten uzmanlık alanı olduğu için çok yetkin ve yetkili insan sayısı çok az. Var olanlarda nitelikli demeyelim 100 üzerinden 50 düzeyinde olanlardır. Bu kalem için 10.000 lira ayrılsa da, insanlar nereden ne geleceğini yani hangi yöntemle ne geleceğini ve okulunun özelliğini çok iyi bilmiyor." LM2

Okul yöneticilerinin görüşlerinde okulun giderleri kategorisinde "hizmet alımı gideri" teması belirlenmiştir. "Hizmet alımı gideri" teması ile güvenliği sağlama, kaloriferi çalıştırma, temizliği yapma, vb. çok çeşitli personel görevlerini sağlamak üzere istihdam edilen personellerin aylıkları ve sigorta bedelleri belirtilmiştir. Her üç kademe için okullarda öğrenci sayısı çok olmasına rağmen personeller ücretlerinin karşılanmasında zorluk yaşandığı için sayıları yeterli olamamaktadır. Okul yöneticilerinden bazılarının hizmet alımı konusuna örnek olabilecek bazı alıntılar şöyledir:

\begin{abstract}
"Okulda 1050 öğrenci ve ikili eğitim olduğu için 07:50 de başlıyor, akșam 18:00 de bitiyor. Normal bir personel 8 saat çalışması gerekirken 10-11 saat arası çalıştırıyoruz. 5 tane personel var. 1 tane personelin, 977 lira maaş ve sigorta gideri (250-300TL SGK primi) ile aylık 5 personel için 7500 liraya denk geliyor. Ödememe şansımı yok. 10 ay ve şubat tatiliyle birlikte 11 ay çok büyük bir gider oluyor." Yazları sadece kadrolu çalışan kalıyor." IOM3

"Okulda kadrolu iki hizmetli ve temizlik için iki sözleșmeli hizmetli çalıştırılıyor. Normalde 3 kişi olması gerekli. Onların ödemelerinde sıkışıyoruz. Kış döneminde kaloriferci için hizmet satın alıyoruz. Kaloriferci için en az 6 ay hizmetli ücreti veriyoruz." OM1

"Gelirin büyük bir kısmı personel gideri olarak kullanılıyor. Personel aylık gideri 25 bin TL. 10 aylık 250000 TL. Okulun personel ihtiyacı karşılansa, başka para verilmese de olur.Çünkü bu ödenek verilse .....her şeye yeter. Güvenlik için Bakanlığın tahsis etmiş olduğu 2 hizmet satın alma ile görevli çalıştırılıyor. Okulun kadrolu 1 hizmetlisi var. 18 kişi (güvenlik, temizlik, memur) Aile Birliği olanakları ile personel olarak çalıştırılıyor. Yemekhanede personel çalıştırıyoruz." MLM5
\end{abstract}

\title{
3.2.Eğitim Finansmanı Politikalarının Uygulama Sorunları
}

Araştırmanın ikinci alt problemi "Okul yöneticilerinin eğitim finansmanı politikalarının uygulanmasında karşılaşılan sorunlara ilişkin görüşleri nelerdir?" şeklindedir. Okul yöneticilerinin görüşlerine göre eğitim finansmanı politikalarının uygulama sorunlarına ilişkin yapılan inceleme neticesinde iki kategori ortaya çıkmıştır: okul temelli ve Bakanlık temelli sorunlar. Okul temelli sorunlar kategorisinde " personel giderlerine ilişkin sorunlar, bütçenin yönetimine ilişkin sorunlar ve eğitim giderinin karşılanmaması" alt kategorileri belirlenmiştir. Bakanlık temelli sorunlar kategorisinde "bütçe miktarının sınırlılığı ve bütçe yönetiminde 
uzmanlaşma sorunu" alt kategorileri belirlenmiştir. Okul yöneticilerinin eğitim finansmanı politikalarının uygulama sorunlarına ilişkin kategoriler ve temalar Tablo 4'te verilmiştir.

Tablo 4.

Eğitim Finansmanı Politikalarının Uygulama Sorunları

\begin{tabular}{|c|c|c|c|c|}
\hline Kategoriler & Alt kategoriler & Temalar & $\mathbf{n}$ & $\%$ \\
\hline \multirow{8}{*}{$\begin{array}{l}\text { Okul temelli } \\
\text { sorunlar }\end{array}$} & Personele & Personel giderinin yüksekliği & 20 & 14,82 \\
\hline & $\begin{array}{l}\text { giderlerine } \\
\text { ilişkin sorunlar }\end{array}$ & Personel eğitimi için giderlerin karşılanmaması & 12 & 8,89 \\
\hline & \multirow{4}{*}{$\begin{array}{l}\text { Bütçenin } \\
\text { yönetimine } \\
\text { ilişkin sorunlar }\end{array}$} & Okullar arası ekonomik fırsat ve imkan eşitsizliği & 6 & 4,44 \\
\hline & & Mali kaynakların süreklilik içermemesi & 6 & 4,44 \\
\hline & & Ödenek takibini yapmanın zorluğu & 6 & 4,44 \\
\hline & & Bağışçı velilerin olumsuz tutumu & 6 & 4,44 \\
\hline & \multirow{2}{*}{$\begin{array}{l}\text { Eğitim giderinin } \\
\text { karşılanmaması }\end{array}$} & Eğitim hizmetlerine bütçe ayrılmaması & 12 & 8,89 \\
\hline & & Kırtasiye bütçesinin sınırlı olması & 8 & 5,92 \\
\hline \multirow{6}{*}{$\begin{array}{l}\text { Bakanlık } \\
\text { temelli } \\
\text { sorunlar }\end{array}$} & \multirow{2}{*}{$\begin{array}{l}\text { Bütçenin kısıtlı } \\
\text { olması }\end{array}$} & MEB bütçesinin yetersizliği & 7 & 5,18 \\
\hline & & MEB tüketim gideri kalemlerinin çeşitliliği & 6 & 4,44 \\
\hline & \multirow{4}{*}{$\begin{array}{l}\text { Bütçe } \\
\text { yönetiminde } \\
\text { uzmanlaşma } \\
\text { sorunları }\end{array}$} & Kaynakların adaletsiz dağıtılması & 16 & 11,86 \\
\hline & & $\begin{array}{l}\text { Bütçe yönetiminde okul yöneticisine yetki } \\
\text { verilmemesi }\end{array}$ & 14 & 10,38 \\
\hline & & Donanım giderlerinin yeterli karşılanmaması & 10 & 7,42 \\
\hline & & $\begin{array}{l}\text { Bakanlığın okuldan istediği ile söylemlerinin } \\
\text { örtüşmemesi }\end{array}$ & 6 & 4,44 \\
\hline \multicolumn{3}{|r|}{ S } & 135 & 100 \\
\hline \multicolumn{5}{|c|}{$\begin{array}{l}\text { Tablo 4'te görüldüğü gibi eğitim finansmanı politikalarının uygulama sorunları çeşitlilik } \\
\text { göstermekte bir katılımcı birden çok görüş belirtmektedir. "Okul temelli yaşanan sorunlar" kategorisinde } \\
\text { katılımcıların görüşlerinin yoğunluklu olarak "personel hizmetinin satın alınması" ile ilişkili (n=32) olduğu } \\
\text { görülmektedir. Katılımcılar bu kategori ile ilişkili olarak "personel giderinin yüksekliği ve personel eğitim } \\
\text { yatıımları giderleri" temalarını vurgulamışlardır. Ikinci olarak katılımcılar bütçenin yönetimindeki } \\
\text { sorunlar alt kategorisinde "okullararası fırsat ve imkan eşitsizliği, mali kaynakların süreklilik içermemesi, } \\
\text { ödenek takibini yapmanın zorluğu ve bağışçı velilerin olumsuz tutumu" temalarını belirtmişlerdir. } \\
\text { Katılımcıların görüşlerinin bazıları "okul temelli sorunlar" kategorisi "personele ilişkin giderler" alt } \\
\text { kategorisi "personel giderinin yüksekliği" teması ile ilgilidir. "Personel giderinin yüksekliği" ilişkin } \\
\text { yöneticilerin görüşlerinden bazı alıntılar şöyledir: }\end{array}$} \\
\hline
\end{tabular}

"ilkokullar için hizmetli ücretini karşılamak zor olduğu için 8 sınıfı 1 hizmetli temizleyecek iken 12 sınıfı 1 hizmetli temizliyor." iOM8

"Giderlerimizin en büyüğü personel gideridir. Devlet ise sadece kadrolu 1 hizmetli veriyor. Sendikal halklardan dolayı o kişiye verebileceğiniz işler kısıtı. 1 tuvalet 1 koridor 6 derslik verebiliyorsunuz. 14 derslik 2 tuvalet veriyoruz. Burası sabah 07:00 akşam 19:00 a kadar açık. Biz diğer personelin giderini aile birliği hesabından ödüyoruz. Anasınıfında 48 aylık, 52 aylık, 60 aylık çocuklar var. 3 ayrı sınıf. Bir sınıfta 25 çocuk var. Pedagojik olarak bir öğretmenin yanına bir yardıma vermemiz gerekli. Ama nasıl?" OM3

"Hizmet almaya çalıştığımız zaman 1600 TL'yi buluyor. Okulda kadrolu iki hizmetli, temizlik için iki sözleşmeli hizmetli çalıştırılıyor. Normalde 3 kişi olması gerekli. Onların ödemelerinde sıkışıyoruz. Kış döneminde kaloriferci için hizmet satın alıyoruz." OM1

"Tüm okullar için asında personel gideri yüksek olduğu için bu ihtiyacın karşılanması çok sıkıntılı. Benim okulumda 32 sınıf, 6 laboratuvar vs. var yani 70 ayrı alanın 3 hizmetli ile temizlenmesi mümkün değilken bazı okullarda hiç hizmetli yok. Yani bir kişinin maliyeti 2600 TL olduğu için." LM5

Okul yöneticilerinin okul temelli sorunlar kategorisi "bütçenin yönetimine ilişkin sorunlar" alt kategorisi "okullar arası ekonomik fırsat ve imkan eşitsizliği" temasında $(n=6)$ toplanabilecek benzer ifadeleri vardır. Bu alt temaya göre katılımcılar tarafından vurgulanan bir alıntı ise şöyledir; 
"Okul düzeyinde politikaların sonucu olarak karşılaşılan sorunlardan biri, ekonomik anlamda fırsat ve imkan eşitliği sorunu. Ikili ilişkilerle para tahsil oluyor diyebiliriz. Olunca oluyor olmayınca da bu iş çözülemiyor. Bu da büyük bir problem. Her defasında birisine şirin gözükmek bana 5 -10.000 TL demek." LM2

Okul yöneticilerinin okul temelli sorunlar kategorisi "eğitim giderinin karşılanmaması" alt kategorisi "eğitim hizmetlerine bütçe ayrılmaması" temasında $(n=12)$ toplanabilecek benzer ifadeleri vardır. Bu temaya örnek olabilecek katılımcılar tarafından vurgulanan bir alıntı ise şöyledir;

"Giderlerden ödenmesinde en çok zorluk çekilen okul dışı faaliyetler çünkü çocukları sürekli bir yerlere götürmek gerekli oluyor. Eğitim sınıftan ibaret değil. Resim sergisi katılım ücreti, öğrenciler için yol parası, bilgi yarışması, vb. birçok madde var. MEB bir ödenek vermiyor." LM1

Okul yöneticilerinin eğitim finansmanı politikalarının uygulama sorunlarına göre yapılan değerlendirmede "Bakanlık temelli sorunlar" kategorisi "bütçe yönetiminde uzmanlaşma sorunu ve bütçenin kısıtlı olması" alt kategorileri oluşturulmuştur. Katılımcılar yoğunluklu olarak "bütçe yönetiminde uzmanlaşma sorunu" $(n=46)$ alt kategorisini vurgulamışlardır. Bütçe yönetiminde uzmanlaşma sorunu ile "kaynakların adaletsiz dağıtılması, bütçe yönetiminde okul yöneticisine yetki verilmemesi, donanım giderlerinin yeterli karşılamaması ve Bakanlığın okuldan istediği ile söylemlerinin örtüşmemesi" temalarını vurgulamışlardır. "Bütçenin kısıtlı olması" alt kategorisinde ise MEB tüketim gideri kalemlerinin çeşitliliği ve MEB bütçesinin yetersizliği sorun olarak belirtilmiştir. "Bütçenin kısıtlı olması" alt kategorisi "MEB bütçesinin yetersizliği" temasına $(n=7)$ göre katılımcılar tarafından vurgulanan bir alıntı ise şöyledir;

"MEB in okullar için ayırdığı bütçe yeterli değil. Güncellenmesi gerekli. Her mali yılda bu ödeneklerin gerçekçi bir şekilde güncellenmesi gerekli. Öğrenci sayısına göre güncelleniyor, ancak yeterli olmuyor. Yeterli olmadığı zaman ilave yapılıyor. Personel aylık gideri çok fazla. Okulun personel ihtiyacı karşılansa, her türlü eğitim malzemesini, donanımı alırım ve tamir parası sorun olmaz." MLM1

Okul yöneticilerinin bakanlık temelli sorunlar kategorisinde "bütçe yönetiminde uzmanlaşma sorunları" alt kategorisi "kaynakların adaletsiz dağıtılması" ( $n=16)$ toplanabilecek benzer ifadeleri vardır. Bu tema Bakanlığın elindeki finansman kaynaklarının dağılımındaki belirsizlikler, temel eğitime kaynak ayrılmaması, kaynakların boşuna harcanması, vb. sorunları içermektedir. Bu alt temaya örnek olabilecek katılımcılar tarafından vurgulanan iki alıntı ise şöyledir;

"Bakanlık düzeyinde eğitim bütçesi ilkokul, ortaokul ve lise olarak düşündüğümüzde dengeli bir dağılım yok. Her okulun payı farklı. Her okul bölgesinde bir havuz oluşturulabilir. Aynı mahallede bir başka okulun geliri bizim 10 katımız olabiliyor. Kırsal kesimdeki okullar çok kötü durumda." OM9

"MEB düzeyinde; öğrenci sayısı, bir önceki yılın gideri, ve MEB durumu dikkate alınarak otomatik bir dağılım oluyor. Ülkemizde siyasi otorite baskın, olduğu için siyasilere göre bütçe ayrılıyor. Bazı illerde çok fazla ya da küçücük bir ilçeye 6 adet okula bilgisayar laboratuarı kuruluyor. Okul benim ihtiyacım yok diyor. Ama otorite baskı yaptığı için ilçeye laboratuar kurulmuş. "LM5

\subsection{Okul Kademelerine Göre Eğitim Finansmanı Politikalarının Yansımaları}

Araştırmanın üçüncü alt problemi "Okul yöneticilerinin okul kademlerine göre eğitim finansmanı politikalarının yansımalarının karşılaştırılmasına ilişkin görüşleri nelerdir?" şeklindedir. Okul yöneticilerinin okul kademlerine göre eğitim finansmanı politikalarının yansımalarının karşılaştırılması ilişkin görüşlerinin incelemesi sonucunda üç kategori ortaya çıkmışır: ilkokul finansmanı, ortaokul finansmanı ve lise finansmanı. Okul yöneticilerinin okul kademlerine göre eğitim finansmanı politikalarının yansımalarının karşılaştırılması ilişkin kategori ve temalar Tablo 6'da verilmiştir.

Tablo 6. 
Okul Kademelerine Göre Eğitim Finansmanı Politikalarının Yansımalarının Karşılaştırılması

\begin{tabular}{|c|c|c|c|c|}
\hline Kategoriler & $\begin{array}{l}\text { Alt } \\
\text { Kategoriler }\end{array}$ & Temalar & $\mathbf{n}$ & $\%$ \\
\hline ilkokulların & Finansman & Velinin katkı sağlaması & 6 & 6,59 \\
\hline \multirow[t]{4}{*}{ finansmanı } & Avantajı & $\begin{array}{l}\text { Öğrencinin yaşının küçüklüğünün mali } \\
\text { kayıpları azaltması }\end{array}$ & 5 & 5,49 \\
\hline & Finansman & Ödenek olmaması & 12 & 13,19 \\
\hline & Dezavantajı & Üst yönetimin ciddiye almaması & 6 & 6,59 \\
\hline & $\begin{array}{l}\text { Finansman } \\
\text { Avantajı }\end{array}$ & $\begin{array}{l}\text { Üst sosyoekonomik gelirli bölgelerde veli } \\
\text { desteği }\end{array}$ & 4 & 4,4 \\
\hline \multirow{5}{*}{$\begin{array}{l}\text { Ortaokulların } \\
\text { finansmanı }\end{array}$} & & Aile birliği desteği & 2 & 2,19 \\
\hline & Finansman & Gelir kaynaklarının olmaması & 8 & 8,79 \\
\hline & Dezavantajı & Veli beklentisinin yüksekliği & 4 & 4,4 \\
\hline & & Davranış sorunlarına bağlı onarım maliyeti & 4 & 4,4 \\
\hline & Finansman & Ödenek verilmesi & 15 & 16,49 \\
\hline \multirow[t]{4}{*}{ Liselerin finansmanı } & Avantajı & Üst sosyoekonomik gelirli veli desteği & 8 & 8,79 \\
\hline & & Ek gelir kaynakları bulabilme & 5 & 5,49 \\
\hline & Finansman & Velinin destek olmaması & 8 & 8,79 \\
\hline & Dezavantajı & $\begin{array}{l}\text { Alt sosyoekonomik düzeyli okullarda gelir } \\
\text { kaynaklarının yetersizliği }\end{array}$ & 4 & 4,4 \\
\hline Toplam & & & 91 & 100 \\
\hline
\end{tabular}

Tablo 6'da görüldüğü okul yöneticilerinin okul kademlerine göre eğitim finansmanı politikalarının yansımalarının karşılaştırımasına ilişkin görüşleri hem mevcut görevli oldukları hem de geçmişte görev yaptıkları okul düzeylerine ilişkindir. Okul yöneticilerinin okul kademlerine göre eğitim finansmanı politikalarının yansımalarının karşılaştırılması ilişkin ilkokul, ortaokul ve lise finansmanı kategorileri ve bu kategorilerin her birinin altında finansman avantajı ve dezavantajı alt kategorileri oluşturulmuştur. En fazla finansman avantajlı olarak lise kademesi $(n=28)$ vurgulanmıştır. En az avantajlı olarak ortaokul kademesi bulunmuştur $(n=6)$. Okul kademeleri arasında "finansman dezavantajı" açısından en yüksek oranda ilkokul kademesi kategorisi $(n=20)$ bulunmuştur. Dezavantajlılık konusunda en az sorunu olan kademe lise kademesi $(n=12)$ olarak görülmüştür.

Okul yöneticilerinin okul kademlerine göre eğitim finansmanı politikalarının yansımalarının karşılaştırılmasına ilişkin "ilkokulun finansmanı" kategorisi "finansman dezavantajlığı" alt kategorisinde "ödenek olmaması ve üst yönetimin ciddiye almaması" temaları belirlenmiştir. Bunların içinde en fazla vurgulanan tema "ödenek olmaması" temasıdır $(n=12)$. Okul yöneticileri ilkokullarda kısmen diğer düzeylere göre harcama kalemlerinin sayısının sınırlı olduğu, öğretmenlerin sınıfları sahiplenmesi nedeniyle ekonomik kayıpların azaltılabildiği ve velinin öğrenci küçük olduğu için sahiplenme oranının artabildiği halde okulların ödenekleri olmaması nedeniyle dezavantajı olduklarını belirtmektedirler. Bir katılımcının "ödenek olmaması" temasına doğrultusunda vurguladığı bir alıntı ise şöyledir;

\footnotetext{
"ilkokullara valilikten veya il özel idareden ayrılan bir bütçe yok. Orta öğretimlere var. Ani çıkan harcamalarda, örneğin su borusunun patlaması ya da bir kaçak olduğu durumlarda ödenemiyor. Örneğin anaokulumuza ek öğretmen almak isteğimizde bunu bile yapamadık ki zaten 15-20 öğrencimizden 35 TL'lik aidatlarının bile ancak \%80'i ödeyebiliyor." iOM4
}

Okul yöneticilerinin okul kademlerine göre eğitim finansmanı uygulamalarının karşılaştırılmasına ilişkin "ortaokulun finansmanı" kategorisi "finansman dezavantajılığı" alt kategorisinde "davranış sorunlarına bağlı onarım maliyeti, veli beklentisinin yüksekliği ve gelir kaynaklarının olmaması" temaları belirlenmiştir. Bunların içinde en fazla vurgulanan tema "gelir kaynaklarının olmaması" $(\mathrm{n}=8)$ temasıdır. Bu tema ortaokulların merkezi bütçeden belirlenen bir finansman kaynağının olmaması, mali giderlerinin merkez yönetim tarafından 
dikkate alınmaması ve özellikle üst yönetimin ortaokulları önemsemediği konusundaki görüşlerle ilişkilidir. Okul yöneticilerinin bu tema doğrultusunda belirttiği bir alıntı ise şöyledir;

"Bir bütçemiz yok. Gelir kaynaklarımız da kısıtlı. Liseler çok güzel fiziki koşullara sahip iken ortaokullar unutulmuş gibi. Ortaokullarda e-yatırıma başvuruyoruz. Sıranın gelmesini bekliyoruz. Veli çocuk büyüdügü, zorunlu hissetmediği için boş verebiliyor ve daha az destek oluyor. Ortaokul üvey evlattır ortaokullar. Devletin görmek, uğraşmak istemediği, bir yerdeyiz. "OM10

Okul yöneticilerinin okul kademlerine göre eğitim finansmanı politikalarının yansımalarının karşılaştııılmasına ilişkin "lisenin finansmanı" kategorisi "finansman avantajı" alt kategorisinde "ödenek verilmesi, üst sosyoekonomik gelirli veli desteği ve ek gelir kaynakları bulabilme" temaları belirlenmiştir. Ancak bazı alt sosyoekonomik düzeyli liselerde gelir kaynaklarının yetersizliği, olanaklarının kısıtlı olduğu ve üst yönetim desteğinin düşüklüğü de belirtilmektedir. Bunların içinde en fazla vurgulanan tema "ödenek verilmesi" temasıdır ( $n=15)$. Bir katılımcının bu tema doğrultusunda belirtilen görüşlerine ilişkin bir alıntı şöyledir;

"Biz ilköğretimlerden daha şanslıyız, devlet tarafından genel bütçeden verilen ödeneklerimiz var, hizmet alımlarımız var, devletin maaşlarını karşıladığı hizmetlilerimiz var bunların 8 ayını devlet, 1 ayını okul aile birliği karşılıyor." MLM1

\subsection{Eğitim Finansmanı Politikalarının Uygulama Sorunlarının Nedenleri}

Araştırmanın dördüncü alt problemi "Okul yöneticilerinin eğitim finansmanı politikalarının uygulama sorunlarının nedenlerine ilişkin görüşleri nelerdir?" şeklindedir. Okul yöneticilerinin eğitim finansmanı politikalarının uygulama sorunlarının nedenlerine ilişkin yapılan inceleme neticesinde dört kategori ortaya çıkmıştır. Bu kategoriler şunlardır: eğitim politikasının niteliği, veliden destek görememe, bütçe yönetimi ve planlama eksikliği. Okul yöneticilerinin eğitim finansmanı politikalarının uygulama sorunlarının nedenlerine ilişkin kategori ve temalar Tablo 7 'te verilmektedir.

Tablo 7

Eğitim Finansmanı Politikalarının Uygulama Sorunlarının Nedenleri

\begin{tabular}{llll}
\hline Kategoriler & Temalar & $\mathbf{n}$ & $\mathbf{\%}$ \\
\hline Eğitim & Rasyonel olmayan ve geçici eğitim politikaları & 9 & 10,84 \\
nolitikasının & Karar vermede aşırı merkeziyetçi tutum & 4 & 4,82 \\
& Okulun mali sorunlarının yeterince dikkate alınmaması & 4 & 4,82 \\
\hline Planlama Eksikliği & Okul gereksinimlerinin yerinde saptanmaması & 9 & 10,84 \\
& Fiziksel yapının yıpranma maliyetinin hesaplanmaması & 4 & 4,82 \\
\hline Veliden destek & Veli işbirliği sorunu- önyargılı olması & 8 & 9,64 \\
görememe & Okul Birliğinin kaynak yaratamaması & 4 & 4,82 \\
\hline Bütçe & Bütçe oluşturmada uzmanlaşma eksikliği & 14 & 16,87 \\
yönetiminde & Bütçe yönetimi konusunda eğitim verilmemesi & 10 & 12,05 \\
yetersizlik & Ulusal Ekonomideki maliyetlerin yüksekliği & 9 & 10,84 \\
& Ödeme işlemlerinin düzensiz verilmesi & 8 & 9,64 \\
\hline Toplam & & 83 & 100 \\
\hline
\end{tabular}

Tablo 7'de görüldüğü gibi eğitim finansmanı politikalarının uygulama sorunlarının nedenleri çeşitlilik göstermekte bir katılımcı birden çok görüş belirtmektedir. Okul yöneticilerinin eğitim finansmanı politikalarının uygulama sorunlarının nedenlerine ilişkin görüşlerinin "eğitim politikasının niteliği, planlama eksikliği, veliden destek görememe ve bütçe yönetiminde yetersizlik" olmak üzere dört kategoride toplandığı görülmektedir. Bunların içinde en çok vurguladıkları kategori "bütçe yönetiminde yetersizlik" $(n=41)$ kategorisidir. Bütçe yönetimi kategorisinde "bütçe oluşturmada uzmanlaşma eksikliği, Hizmetlerin karşılanmasına yönelik ulusal ekonomideki maliyetlerin yüksekliği, okul üyelerine bütçe yönetimi konusunda yöneticilere ve öğretmenlere eğitim verilmemesi ve ödeme işlemlerinin 
düzensiz yürütülmesi" temaları belirlenmiştir. Bunların içinde en fazla vurgulanan tema "bütçe oluşturmada uzmanlaşma eksikliği" temasıdır $(n=14)$. Bütçe oluşturmada uzmanlaşma eksikliği teması üst yönetimin kaynakları dengesiz dağıtması, bu konuda profesyonel bir tutum izlenmemesi, personel ücretlerine bütçede yeterince yer verilmemesini ifade etmektedir. Katılımcıların bu konudaki görüşlerine ilişkin iki alıntı ise şöyledir;

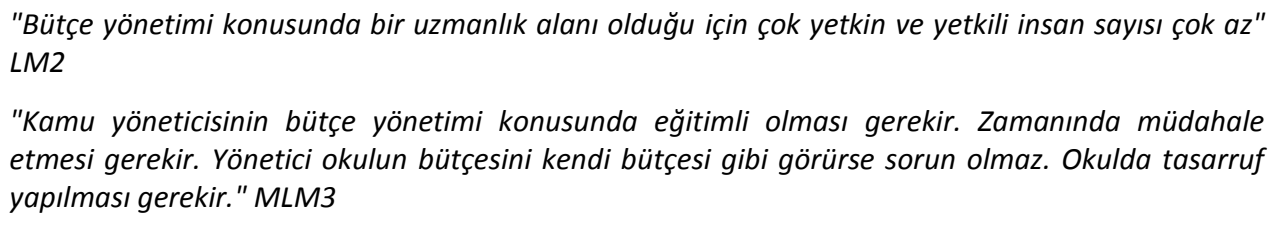

Okul yöneticilerinin eğitim finansmanı politikalarının uygulama sorunlarının nedenlerine ilişkin ikinci olarak en çok vurguladıkları kategori "Eğitim politikasının niteliği" $(n=17)$ kategorisidir. Eğitim politikası kategorisinde "rasyonel olmayan ve geçici eğitim politikaları, karar vermede aşırı merkeziyetçi tutum ve okulun mali sorunlarının yeterince dikkate alınmaması" temaları belirlenmiştir. Bunların içinde en fazla vurgulanan tema "rasyonel olmayan ve geçici eğitim politikaları" temasıdır $(n=9)$. "Rasyonel olmayan ve geçici eğitim politikaları" teması MEB politikalarının belirlenmesinde toplumun eğitim gereksinimine ve eğitim kurumlarına kaynak ayrılması, eğitim yatırımlarının yetersizliği ve okul merkezli gereksinimlerin temel alınmaması ile ilişkilidir. Bazı katılımcıların bu konudaki görüşüne ilişkin alıntılar şöyledir;

\begin{abstract}
"Eğitime çok fazla kaynak ayrılmıyor. Dünya genelinde eğitim kaynaklarının sağlanması yavaş yavaş liberalizm doğrultusunda devletten çekiliyor, halka aktarılıyor." iOM3

"Bizi yönetenlerin (bakan) genelde bu meslek içinden yetişip gelmemesi en büyük neden. Eğitim uzun süre gerektiren bir uğraş olduğu için insanlara zor gelip genelde yüzeysel yaklaşıp geçici politikalar ve çözümler üretiyorlar. Örneğin bir mahalle kuruyorsunuz ve bunu çabucak yapmak için altyapısız vs. kuruyorsunuz ve ilk yağışta da bölgenin elinden gelen sadece oturup felaketi beklemek oluyor. Bizde aynı durumdayız." IOM4

"Eğitim politikası günü kurtarmaya yönelik, ileriye dönük yatırımlar yapılmıyor. Bir okulun yeni öğretim yılı başında en azından 10000 TL ödeneğe ihtiyacı var. Sıralar, duvarlar boyanacak, tamiratlar yapılacak." LM5
\end{abstract}

Okul yöneticilerinin eğitim finansmanı politikalarının uygulama sorunlarının nedenlerine ilişkin diğer bir kategori "planlama eksikliği" dir. Bu kategoride "Okul gereksinimlerinin yerinde saptanmaması ve fiziksel yapının yıpranma maliyetinin hesaplanmaması" temaları belirlenmiştir. "Okul gereksinimlerinin yerinde saptanmaması" temasında $(n=9)$ toplanabilecek benzer ifadeler vardır. Okul yöneticileri gereksinimlerin yerinde saptanmaması teması doğrultusunda ödeneklerin kullanımında esnek olunamaması ve kaynak ayrılırken okul temelli gereksinimlerin dikkate alınmaması nedenlerini belirtmişlerdir. Bu temaya göre katılımcılar tarafından vurgulanan bir alıntı ise şöyledir;
"Okullara kaynak ayrılırken sadece öğrenci sayısı değil, kurumun genel giderleri ve diğer ölçütlerinin dikkate alınması gerekir. Okul yönetiminin hazırladığı bütçe dikkate alınmalıdır. Satın alma sürecinde uygulanan ilkeler ve kuralların esnek olmaması diğer bir sorundur. MEB görmek istediğini söylüyor. Şekil olarak görmek istiyor. Objektif olarak MEB'den bir görevli gelse sorunumuzu dinlese. Hakikaten okulda yapılan işler incelense ve birlikte çözümler üretsek. MEB miadı geçmiş eski kuralları uygulamaya çalışıyor." MLM3

Okul yöneticilerinin eğitim finansmanı politikalarının uygulama sorunlarının nedenlerine ilişkin son kategori ise "veliden destek görememe" dir. Bu kategoride "okul aile birliğinin kaynak yaratamaması, velilerin ekonomik durumunun düşüklüğü ve veli işbirliği sorunu" temaları belirlenmiştir. Veli işbirliği sorunu temasında $(n=8)$ toplanabilecek benzer ifadeleri vardır. Veli işbirliği sorunu teması, kaynak yönetimi konusunda ve okul birliğinin 
çalışmalarına katılma konusunda velinin önyargılı olması ve bunun sonucu olarak işbirliği yapmamayı tercih etmesini içermektedir. Okul yöneticilerinin görüşlerinden bu temaya ilişkin bir alıntı ise şöyledir;

"Ortaokulda ise veli inancını sisteme yitirmiş oluyor.4 yıl hırpalanmış oluyor, bağış ve aidat oranı düşüyor. Bütçe oluşturmak okul müdürü ve aile birliğindeki kişilere bağlı. Öyle okullar oluyor ki okul müdürü aile birliğini okula sokmuyor ya da aile birliği müdüre güvenmiyor. Etkin çalışmazlarda hiçbir şey yok." OM3

\subsection{Eğitim Finansmanı Politikalarının Sorunlarına ilişskin Çözümler}

Araştırmanın beşinci alt problemi "Okul yöneticilerinin eğitim finansmanı politikalarının sorunlarının çözümüne ilişkin görüşleri nelerdir?" şeklindedir. Okul yöneticilerinin eğitim finansmanı politikalarının sorunlarının çözümüne ilişkin görüşlerinin incelemesi sonucunda dört kategori ortaya çıkmıştır: yeni eğitim finansmanı politikası, yönetim yapısı, finansman uzmanlık bilgisi geliştirme ve kaynak kullanımı. Okul yöneticilerinin eğitim finansmanı politikalarının sorunlarının çözümüne ilişkin kategori ve temalar Tablo 8'de verilmiştir.

Tablo 8

Eğitim Finansmanı Politikalarının Sorunlarına iliş̧kin Çözümler

\begin{tabular}{llll}
\hline Kategoriler & Temalar & $\mathbf{n}$ & $\mathbf{\%}$ \\
\hline \multirow{2}{*}{ Yeni eğitim } & Okulda kamu kaynaklarının payının artırılması & 18 & 19,57 \\
finansmanı & Veliyi mali destek konusunda özendirme politikası & 6 & 6,52 \\
politikası & Yerel ve okul yönetimlerle yetki paylaşımı & 6 & 6,52 \\
\hline \multirow{3}{*}{ Yönetim yapısı } & Okul aile birliği kaynaklarını geliştirme & 4 & 4,35 \\
& Okulların ihtiyaç analizi için bir yapı kurulması & 12 & 13,04 \\
& Okul gereksinimlerinin yerinde saptanması ve çözümü & 6 & 6,52 \\
\hline Finansman & Ödeneklerin izlenmesinde etkili denetim yapısı kurulması & 6 & 6,52 \\
uzmanlık bilgisi & Okul üyelerine bütçe yönetimi eğitimi & 8 & 8,7 \\
geliştirme & Finansman uzmanı görevlendirme & 6 & 6,52 \\
\hline Kaynak & & & 12 \\
kullanımı & Ökili planlama yapılması & 13,04 \\
& Öğrenci başına ödenek verilmesi & 4 & 4,35 \\
\hline Toplam & & 4 & 4,35 \\
\hline
\end{tabular}

Tablo 8'de görüldüğü okul yöneticilerinin eğitim finansmanı politikalarının uygulama sorunlarının çözümlerine ilişkin görüşleri örgüt yapının farklı öğelerine ilişkindir. Bir katılımcı birden çok görüş belirtmektedir. Okul yöneticilerinin eğitim finansmanı politikalarının uygulama sorunlarının çözümlerine ilişkin en çok vurguladıkları kategori "yeni eğitim finansman politikası" ( $n=34)$ kategorisidir. "Yeni eğitim finansman politikası" kategorisinde "veliyi mali destek konusunda özendirme politikası, okul aile birliği kaynaklarını geliştirme, okulda kamu kaynaklarının payının artırılması ve yerel ve okul yönetimleriyle yetki paylaşma" temaları belirlenmiştir. MEB'in özel kaynakların artırılması beklentisine karşılık yöneticiler, veliyi mali destek konusunda özendirme politikası, okulun öz kaynak geliştirmesi ve bu nedenle uygulamacılar ve Bakanlığı ortak dili kullanması gerektiğini belirtmektedirler. MEB'in bütçe yönetimi konusunda yerel ve okul yönetimleriyle yetki paylaşımı, okul yönetimlerinin karar verme sürecine katılması ancak sıkı bir denetlenme sisteminin yürütülmesi de çözüm olarak görülmektedir. Temalar içinde en fazla vurgulanan tema "okulda kamu kaynaklarının payının artırılması" temasıdır ( $\mathrm{n}=18$ ). "Okulda kamu kaynaklarının payının artırılması" teması okulların giderlerinin karşılanmasında tüketim kalemlerinin ve fiziksel yapının iyileştirilmesi için yapılacak ödemelerin daha düzenli bir şekilde genel bütçeden ödenmesine ilişkin çözümleri önermektedir. Bir katılımcının bu temaya göre vurguladığı bir alıntı ise şöyledir; 
"Okulların finansman kaynaklarını valilik veya bakanlığın sağlaması gerekir. Yerele indirgenirse bu iş yürümez. Politize olabilir. Eğitim sosyal devlet politikasının bir parçasıdır. Hükümet politikası olmamalı. Okulun ihtiyaçlarını karşılama okula bırakmamalıdır." IOM2

Okul yöneticilerinin eğitim finansmanı politikalarının uygulama sorunlarının nedenlerine ilişkin ikinci olarak en çok vurguladıkları kategori "Yönetim yapısı" ( $n=24)$ kategorisidir. Yönetim yapısı kategorisinde "okulların ihtiyaç analizi için bir yapı kurulması, okul gereksinimlerinin yerinde saptanması-çözümü ve etkili denetim yapısı kurulması" temaları belirlenmiştir. Okul gereksinimlerinin yerinde saptanması ve çözümü okullara sorun odaklı çözüm geliştirilmesini temel alma ve bu doğrultuda kurulacak yerel komisyonların talep ve teminini sağlama, ödeneklerin izlenmesinde etkili denetim yapıları kurma, vb. çözümler bu doğrultudadır. Bunların içinde en fazla vurgulanan tema "okulların ihtiyaç analizi için bir yapı kurulması" temasıdır ( $\mathrm{n=12}$ ). "Okulların ihtiyaç analizi için bir yapı kurulması" okulların amaç ve gereksinimlerini gerçekçi bir şekilde değerlendirecek birimlerin görevlendirilmesi ile ilişkilidir. Bu tema doğrultusunda belirtilen görüşlere ilişkin bazı alıntılar şöyledir;

"Toplumun çıkarlarını gözeten insanlar yönetimde görev almalı, ödenek istenmeden önce objektif bir piyasa araştırması yapılmalıdır. Bir ekip görevlendirilip alan taraması yapılabilir. Her kurumun bütçesi daha iyi değerlendirilebilir." MLM3

Okul yöneticilerinin eğitim finansmanı politikalarının uygulama sorunlarının nedenlerine ilişkin diğer bir kategori "Finansman uzmanlık bilgisini geliştirme" kategorisidir. Finansman uzmanlık bilgisini geliştirme kategorisinde "Finansman uzmanı görevlendirme ve okul üyelerine bütçe yönetimi eğitimi" temaları belirlenmiştir. Bu temalar okulda eğitim finansmanlığı konusunda bilgi eksikliği ve iş yükü nedeniyle bir uzman görevlendirme, sorunların yönetici dışında bir uzman tarafından çözülmesi, okulun bir satın alma birimi olması veya işletmeden sorumlu müdür yardımcısı eğitilmesi ve görevlendirilmesine dayanmaktadır. Bunların içinde en fazla vurgulanan tema " Okul üyelerine bütçe yönetimi eğitimi" temasıdır $(\mathrm{n}=8)$. "Okul üyelerine bütçe yönetimi eğitimi" teması okulların finansman kaynaklarının kullanımında öğretmenlerin destek olamaması ve yöneticinin iş yükü nedeniyle bu konuda bilgilendirilmesini sağlama ile ilişkilidir. Bu tema doğrultusunda katılımcılar tarafından belirtilen iki alıntı ise şöyledir;

\footnotetext{
"Yöneticiler finansman kaynağı kullanması ve sistemlerin işleyişi konusunda seminer görmelidir." LM3

"Öğretmen yıllarca alışmış, okul idaresi onun işini halleder, okul idaresi çözer. O yüzden her şey mali olarak okul idaresinin üzerine yıkılıyor. Bu sefer de odadan kafayı çıkartamıyorsunuz, okulda ne olduğundan haberiniz yok, gözlem yapamıyorsunuz. Eğitim öğretim nasıl yürüyor ondan bir haberiniz olmuyor. Asıl işimizi unutuyoruz.Öğretmenlerin de bu konuda bilgilendirilmesi yararlı olur."LM2
}

Okul yöneticilerinin eğitim finansmanı politikalarının uygulama sorunlarının nedenlerine ilişkin son kategori ise "kaynak kullanımı " kategorisidir. Kaynak kullanımı kategorisinde "etkili planlama yapılması, öğretmenin mesleki gelişimi için ödenek verilmesi ve öğrenci başına ödenek verilmesi" temaları belirlenmiştir. Bunların içinde en fazla vurgulanan tema "etkili planlama yapılması" temasıdır $(n=12)$. Etkili planlama yapılması teması katılımcıların kaynakların dengeli ve adaletli dağıtımı, teknik sorunların çözümünde standart hizmet alımlarının olması ile ilişkilidir. Okul yöneticilerinin etkili planlama yapılmasına örnek olabilecek bir alıntı ise şöyledir;

\footnotetext{
"Planlanan işlerin yürütülmesini engelliyor. Stratejik planlar yapılması gerekli. Ama uygulamada tersi oluyor. Önce harcama sonra planlama oluyor. Ülkemizde hareketlilikten, mevzuat değişikliklerinden, politikanın değişkenliğinden mevzuat uygulanmıyor. Mevzuat delindiği zaman iş ikili ilişkilerle yürüyor. iki sistem varmış gibi oluyor. Bir sistemde kurallar var. Diğerinde herşey kendi kendine gidiyor. Her okul müdürü senede bir kez Bakanlık'a gider. Üst yönetime yakın, iletişimi iyi olan
} 
finansman kaynağını alıyor, ancak diğerleri küsüyor. Daha nesnel yürütülürse bu sorunlar olmaz." MLM5

\section{SONUÇ, TARTIŞMA VE ÖNERILER}

Bu araştırma ile okul yöneticilerinin eğitim finansmanı politikaları, onun sonuçlarına ilişkin görüşleri belirlenmeye ve buna bağlı yaşanan sorunlar açısından öneriler sunulmaya çalışılmıştır. Okul yöneticilerinin finansman kaynaklarına ilişkin görüşlerinin okulun gelirleri ve giderleri olmak üzere iki alanda toplandığı bulunmuştur. Okulun gelirleri kategorisinde finansman kaynaklarının sınırılığına karşın okulun giderleri kategorisinde ise giderlerin oldukça çeşitli olduğu ve okul müdürlerinin okulun giderlerinin çoğunlukla kamu kaynaklarına dayalı olarak ödenmesi gerektiğini destekledikleri görülmüştür. Özer, Demirtaş ve Ateş'in (2015) çalışmasına göre okulların gelir ve giderleri arasında bir dengesizlik bulunmakta ve giderlerinin gelirleri aşması nedeni ile sorunlar ortaya çıkmaktadır. Okullarda özellikle teknolojik araçgereçlerin bakım ve onarım masrafları gider kalemlerinde sürekli bir artışa neden olmaktadır. Hoşgörür ve Aslan'a (2014) göre, müdürler kamu kaynaklarından eğitim ve öğretime ayrılan kaynak ve bu kaynakların okullara dağılımının yetersiz olduğunu belirtmişlerdir. Yetersiz kaynaklar, okul müdürlerinin pek çok alanda kısıtlamalar yaparak okulun gereksinimlerini ucu ucuna karşılayabilmesine neden olmaktadır. Ak'ın (1997) çalışmasında ise kamu bütçesinden ayrılan \%4.61'lik payın diğer ülkelerle kıyaslandığında çok düşük olduğu ve özel idare bütçelerinden eğitime ayrılan payın da il düzeyinde eğitime yapılan yatırımları karşılamadığı ifade edilmiştir. Altuntaş'a (2005) göre okul müdürleri ilköğretim okullarının finansmanının birinci sırada "devlet tarafından" ikinci sırada, "veliler" ve "devlet, belediyeler, il özel idareleri, gönüllü kuruluşlar ve veliler", üçüncü sırada ise "il özel idaresi" tarafından karşılanması gerektiğini düşünmektedir. Gümüşeli ve Hacıfazlıoğlu'na (2009, s.191) göre eğitimin zorunlu ve parasız olduğu belirtilse de, genel olarak okul giderlerinin finansmanı velilerden toplanan bağış ve aidatlar ile karşılanmaya çalışılmaktadır. Alpay'ın (2011) araştırmasında ise okul müdürlerinin tamamı okulun ihtiyaçlarını bütçe dışı kaynaklardan sağladıklarını belirtmektedirler. Öte yandan Türkiye'de öğrenci başına yıllık harcama miktarı OECD ortalamalarının altında seyretmektedir. Merkezi idare, milli bütçeden sağladığı kamu kaynaklarını, faaliyet ve çalışan, eğitim materyali gibi personel masrafları için kamu kurumlarına ve (özel eğitimdeki öğrenciler için) özel kuruluşlara ayırmaktadır. Eğitim reformlarının finansmanı hükümetin yanı sıra uluslararası örgütler, özel kuruluşlar ve sivil toplum kuruluşları aracılığıyla sağlanmaktadır. Genelde eğitime yapılan harcamaların toplamı OECD ortalamasının daha gerisindedir. 2010 yılında devlete bağlı ilköğretim, ortaöğretim ve orta eğitim sonrası-yüksek eğitim düzeyinde olmayan eğitim kurumlarında öğrenci başına yapılan kamu harcamasının miktarı 2.008 USD'yken (OECD ortalaması 8.412 USD'dır), özel eğitim kurumları için bu rakam 2.413 USD'dır (OECD ortalaması 5.029 USD'dır) (OECD, 2013). Dolayısıyla kaynakların daha az ayrılması okullarda gelir ve gider dengesinin sağlanması sürecinde sorunların ortaya çıkmasına ve okullar arası eşitsizliklerin oluşmasına neden olmaktadır. Konsolide bütçeden eğitime ayrılan pay düşerken halkın eğitime katkılarının artması beklenmektedir ancak halkın eğitime katkısında büyük düşüşler olmuştur. Diğer bir deyişle, halk katkılarında belirli bir istikrar görmek mümkün görünmemektedir. Bu nedenle gelir ve gider dengesinin sağlanamadığı söylenebilir (Tuzcu, 2004). Güngör ve Göksu'ya (2013) göre bir ülkede eğitim hizmetinin nicel ve nitel düzeyi ise eğitim için ayrılan mali kaynaklara ve bunlarla sayesinde alınan girdilerin niteliğine ve niceliğine, eğitim teknolojisine ve eğitim sisteminin yapı ve işleyişine bağlı olarak artmaktadır. Alanyazın bu araştırmanın bulgularına göre kamu, özel ve karma finansman modelleri dikkate alındığında okul yöneticilerin daha çok kamu finansman modelini desteklediği söylenebilir. Ancak uygulamada karma finansman modelinin kullanılıyor olması giderlerin kim tarafından karşılanacağı konusunda öngörüsüzlüğü 
artırabilmektedir. Bu da eğitim finansmanı politikasının uygulanmasında eğitimi olmayan yöneticilerin zor durumda kalmasına neden olmaktadır.

Okul yöneticileri eğitim finansmanı politikalarının uygulama sorunlarını okul temelli ve Bakanlık temelli sorunlar olarak belirtmişlerdir. Okul temelli sorunlar arasında "personele ilişkin giderler, bütçenin yönetimine ilişkin sorunlar ve eğitim giderinin karşılanmaması" konuları; Bakanlık temelli sorunlar arasında ise "bütçe miktarının sınırlılığı ve bütçe yönetiminde uzmanlaşma sorunu" konuları sayılmıştır. Özer, Demirtaş ve Ateş'in (2015) çalışmasına göre müdürler okullara doğrudan finansman destek sağlayan bir sistemin olmamasının, bütçe oluşturmada ve yönetmede zorlayan en ciddi sorun olduğunu belirtmişlerdir. Hoşgörür ve Arslan'a (2014) göre okullar kendi kaynaklarını yaratma çabası içindedirler. Okul müdürlerine göre, yetersiz olan kaynaklar okullara bazen geç aktarılmakta, bu durum da zaten sıkıntılı olan okulu ayrıca zora sokmaktadır. Müdürlerin bir kısmı kaynakların okullara adil dağıtılmadığını ve kaynak dağıtımında kurumların ihtiyaçlarının göz önüne alınmadığını belirtmektedirler. Hoşgörür ve Arslan'ın (2014) bu bulgusu bu araştırmanın bulgularını desteklemektedir. Diğer yandan Menteşe, Üstün ve Gökdelen'in (2012) araştırma bulgusu da okulların öğretim yılı boyunca karşılaştıkları giderlerin çeşitlenerek arttığını ve buna karşııı devlet tarafından verilen ödeneklerin azaldığını göstermektedir. Dolayısıyla kamu kaynakları ile karşılanamayan okul giderlerinin, resmi olmayan (ek özel gelir kaynakları) mali kaynaklar ile karşılanmaya çalışılması sonucunu doğurmaktadır. Alpay'a (2011) göre okul yöneticileri en çok bütçenin yetersizliği, özellikle temizlik elemanı başta olmak üzere yardımcı personel yetersizliğinden, okulların fiziki intiyaçları ve donanım eksikliklerinden dolayı sorun yaşamaktadırlar. Çınkır (2010) tarafından yürütülen bir çalışmada okul müdürlerinin bütçe konusunda en fazla okulun özerk bir bütçesinin olmaması, devlet bütçesine sağlanan eğitim katkılarının okullara yansıtılmaması ve maddi kaynak yetersizliği olarak sorunlarını yaşadıkları belirlenmiştir. Walker ve Morton'a (2011) göre bütçenin düşük olması çalışanlar arasında soruna sebep olurken aynı zamanda öğrencilere sunulan programın ve eğitimin kalitesini olumsuz etkilemektedir. Araştırmaya katılan okul müdürlerinin yarısı bütçenin azalmasının sınıflardaki öğrenci sayılarının artmasına ve program dışı verilen kursların azalmasına neden olduğunu belirtmektedir. Dolayısıyla alanyazın ve bu araştırmanın bulguları Türkiye'deki eğitim finansmanı politikalarının kapsamında olan karma modelin uygulanmaları temelinde değerlendirilebilir. Ancak karma modelin uygulanması, okulların sahip olduğu olanaklar açısından farklılıklar göstermesi nedeniyle görüşülen okul müdürlerinin sorunlar yaşadığını göstermektedir. Diğer taraftan eğitim finansmanı eğitimsel amaçlara ulaşmanın bir aracı ise bu durum okullarda öğrencilerin fırsat ve imkan eşitliği açısından dezavantajlı olması ile sonuçlanabilir.

Okul yöneticilerinin okul kademelerine göre eğitim finansmanı politikalarının yansımalarının karşılaştııılmasına ilişkin ilkokul, ortaokul ve lise finansmanı kategorileri ve okul kademelerine göre ilgili kademenin finansman avantajı ve dezavantajı ile ilgili görüşler vurgulanmıştır. Alanyazında bu araştırmanın bulgularını doğrudan destekleyen bir araştırmaya erişilememiştir. Ancak Kavak, Ekinci ve Gökçe'nin (1997) ilköğretimde yaptıkları araştırma bu kademeyi betimleme açısından değerlendirilebilir. Buna göre tüm eğitim kademelerinde olduğu gibi, ilköğretimde sayı ve nitelik açısından ulaşılan durum ile uluslararası göstergeler dikkate alındığında, devlet bütçesinden eğitime ve ilköğretime ayrılan kaynaklar yetersizdir. Mevcut kaynak akışıyla, geçmişin açıklarını ve günümüzün gereksinimlerini karşılamak mümkün görünmemektedir. Bu durum, ilköğretime kaynak sağlama ve kaynak dağıtımı konularında yeni yaklaşımları ve açılımları gerektirmektedir. Altuntaş (2005), Yolcu (2007) ve Alpay'ın (2011) ilköğretimde yaptıkları araştırma bulgularına göre kamu kaynaklarının sınırlı olması okul müdürlerinin özel kaynaklar aramasını gerektirmesi bu okullar açısından bir dezavantaj olarak değerlendirilebilir. Aynı zamanda Alpay'ın (2011) çalışmasında okul müdürlerinin ortaöğretime devlet tarafından ödenek verilmesini eleştirmeleri ve bu tür ödeneğin ilköğretimlere 
verilmesinin gerektiğini belirtmeleri ile bu araştırmanın bulgusu ile benzer doğrultudadır. Sonuç olarak okul kademeleri kendilerine özgü nitelik taşıması nedeniyle okul müdürlerinin görüşlerinde eğitim finansmanı politikalarından okulların bir kısmı olumlu etkilenmekte bir kısmı da olumsuz etkilenmektedir. Genel bütçeden kaynak ayrılan okullar nispeten avantajlı görülmekte iken kaynak ayrılmayan ya da daha az ayrılan okullar dezavantajlı görülmektedir. Çünkü okulların yarattığı kaynaklar süreklilik taşıyamamaktadır. Buna ek olarak bulgular, ilkokul ve ortaokul yöneticilerinin yanında genel lisede veya meslek lisesinde görevli olan katılımcıların da diğer kademelerin durumunu (ilkokul ve ortaokulların durumunu) değerlendirmede bu okulları dezavantajlı olarak görmelerini engellememesi açısından önemlidir.

Okul yöneticileri eğitim finansmanı politikalarının uygulama sorunlarının nedenleri olarak eğitim politikasının niteliği, veliden destek görememe, bütçe yönetimi ve planlama eksikliği konularını görmektedirler. Kavak ve Ekinci'ye (1994) göre finansman sorunlarının içsel nedenleri; eğitim maliyetlerinde meydana gelen artışlar, öğretim kadrosunun verimliliğinin yetersizliği, okul başarısızlıklarının getirdiği finansman kayıpları, çok sayıda burs girmesi ve burslarda meydana gelen yükselmeler, finansman kaynaklarının bileşimi ve kullanımında ortaya çıkan yetersizliklerdir (kötü bir bütçe yönetimi); dışsal nedenler ise; hızlı nüfus artışı, gelişmiş ülkelerde, eğitimin teknolojiyi içeren bir talep olarak şekil değiştirmesi, dış borçların artması, dış ödemeler dengelerinin açık vermesi, kamunun çevre sorunları, büyük alt yapı projeleri gibi kamu finansmanı ile desteklenen hizmetlere daha fazla kaynak ayırması ve benzeri ihtiyaçların bütçelerden pay almaya başlaması, kamunun gelir kaynaklarının arttırılmasına yönelik faaliyetlerin yetersizliği, işsizlik ve istihdam şartlarında meydana gelen değişmeler ve yeniden eğitim ihtiyaçlarıdır. Alpay'a (2011) göre okul müdürleri temizlik elemanı yetersizliği nedeniyle personel çalıştırmaya gereksinim duymaktadırlar. Okulların insan kaynağı planlaması yapılmadığında okul müdürlerinin önüne bir sorun olarak çıkmaktadır. Kavak ve Ekinci'ye (1994) göre eğitimin maliyetlerindeki sürekli artışlar ve diğer toplumsal gereksinimler nedeniyle ulusal bütçelerden eğitime ayrılabilecek kaynakların sınırlı kalmıştır. Eğitim hizmetlerini daha az maliyetle sağlayabilecek stratejiler ile eğitimin niteliğinden ödün vermeksizin, amaçlarından sapmaksızın daha fazla sayıda öğrenciye eğitim hizmeti sunabilmek veya birim maliyetlerin düşürülmesi mümkün olabilir. Bu yolla, eldeki kaynaklar daha etkin bir biçimde kullanılabilir. Bottoms ve Schmidt-Davis'e (2010) göre bazı okul bölgelerinde okulun bütçesini belirlemede okul müdürüne yetkiler verilmektedir. Yetki verilmesi, diğerlerine göre daha çok kaynağa gereksinimi olan okullara ek kaynaklar sağlanmasını ve okul müdürü, öğretmen ve öğrencinin zamanını etkili kullanmasını sağlayabilmektedir. Bu durumda okul müdürlerine yetki verilmemesi de çözümlerin gecikmesine neden olabilmektedir. Kavak ve Ekinci'ye (1994) göre özel harcamaların toplam eğitim harcamaları içindeki payının yüksek olmasının eğitimde eşitlik açısından sorun yaratmasının nedeni, bu harcamaların miktarının gelir grupları arasında büyük oranda dengesiz olmasıdır. En zengin \% 20'lik kesim toplam gelirinin \% 8'ini eğitim, sağlık ve kültür hizmetlerine harcarken, en yoksul \% $20^{\prime}$ lik kesim ancak \% 3'ünü bu hizmetler için kullanabilmektedir. Bu da en zengin \% $20^{\prime}$ lik kesimin yaptığı eğitim harcamalarının, en yoksul \% 20'lik kesimin eğitim harcamalarının 21 katından fazla olduğunu göstermektedir. Bu bulgu ile bu araştırmanın bulgusunu özellikle sosyoekonomik düzeyi düşük bölgelerdeki okullarda "velinin destek vermemesi" bulgusunu desteklemektedir. Ekinci'ye (1994) göre bu da en zengin dilimin toplam gelirinin en yoksul dilimin toplam gelirinin 10 katı olduğu Türkiye isstatistik Kurumu (TUiK) (2016) verilerine göre ise yaklaşık 8 katı olduğu hesaba katıldığında, bu farkın eğitim harcamalarında daha da artması özellikle araştırma kapsamındaki okullarda eşitsizliklerin yeniden yaratılması olasılığını güçlendirebilir. Aslında alanyazın ve bu araştırmanın bulgusu yöneticilerin eğitim finansmanı politikalarının uygulama sorunlarının nedeni olarak çoğunlukla karma finansman modelini düşündüklerini göstermektedir. Aynı zamanda bu bulgu okul yöneticilerinin kamu finansmanı modelini benimsemelerinden, 
velilerin sosyoekonomik düzeylerinin düşük olmasından dolayı zaten öğrencinin öğrenim, fırsat ve yaşam maliyeti ödemekte zorlandıklarını deneyimlemelerinden ve politika uygulayıcılarının MEB'in örgütsel yapısının iyi tanımamasından kaynaklanabilir.

Okul yöneticilerinin eğitim finansmanı politikalarının sorunlarının çözümüne ilişkin görüşleri yeni eğitim finansmanı politikası, yönetim yapısı, finansman uzmanlık bilgisi geliştirme ve kaynak kullanımı konularında toplanmıştır. Alpay'a göre (2011) okul müdürleri ilköğretime bütçeden kaynak aktarılarak devlet okullarında eğitimin parasız olmasının sağlanmasını önermektedirler. Okul müdürleri, öncelikle finansmanın devlet tarafından karşılanmasını, bunun mümkün olmaması durumunda velilerden ekonomik durumu düşük olanlar dışında zorunlu bağış alınmasını talep etmektedirler. Yerel yönetimlerin okullara verdikleri desteğin azımsanmayacak düzeyde olduğu da görülmekte, bu durumun yasal düzenlemelerle daha işlerlik kazandırılması gerektiği ortaya çıkmaktadır. Özmen ve Yalçın'a (2011) göre kamu kaynaklarından ayrılan ödeneklerle intiyaçlarını karşılayamayan eğitim kurumları, ihtiyaçlarını karşılamak için kamu dışından finans desteği sağlamanın yollarını aramaktadırlar. Bottoms ve Schmidt-Davis'e (2010) göre gelecekte en büyük sorunlardan biri eğitim sisteminin ekonomik kısıtılıklardır. Birçok ülkede daha keskin olarak öne çıkması muhtemeldir çünkü şimdi bile geçmişse göre sağlık, barınma ve endüstri talebi ile yarışır durumdadır. Son on yılda çok hızlı bir yükselme yaşanmıştır. Bu da eğer eğitimin daha iyi meslekler kazandırması ve daha çok çocuğun talebini karşılaması isteniyorsa eğitimcilerin ve eğitim planlamacılarının yeni kaynaklar bulabilmesi amacıyla eğitim finansmanını daha iyi öğrenmeleri gerektiğini göstermektedir. Fakat bu konudaki başarı yani daha büyük ve iyi eğitimsel sonuçlara ulaşma sahip olunan kaynakların dışında yeni kaynaklara daha çok ilgi gösterilmesini gerektirmektedir. Diğer taraftan bu araştırmada okul yöneticileri uygulanan karma finansman modeli doğrultusunda eğitimden yararlananların da eğitime finansman kaynağı sağladıklarını ancak bu katkının gereksinimlerini karşılamada yeterli olamadığını belirtmektedirler. Artan eğitim talebinin karşılanması için yeni beklentiler oluşmaktadır. Hali hazırda uygulanan eğitim finansmanı politikalarına ilişkin okul müdürlerinin önerilerinde finansmanı kullanma ve yürütme konusunun özellikle vurgulanması politikaların hazırlanması kadar uygulanmasında yetkililerin yetkinlikleri konusunda bazı sorunları gözlemlemesi nedeninden kaynaklanabilir.

Araştırmanın problemi doğrultusunda okul yöneticilerinin eğitim finansmanı politikalarına ilişkin görüşleri değerlendirilmiştir. Okul müdürlerinin görüşlerinin okullarında yaşanan kaynak yetersizliğini temel alarak eğitim finansmanı politikalarına ilişkin eleştiri ve çözümlerine dayalı bir içeriğe sahip olduğu görülmüştür. Bu bağlamda araştırmanın sonuçları doğrultusundaki öneriler şunlardır:

1.Okul yöneticileri okullarının giderlerinin karşılanması doğrultusundaki taleplerine duyarsızlık gösterildiğini düşünmektedirler. Okullardaki finansman yetersizliğinin giderilmesi amacıyla yeni eğitim finansmanı politikaları merkezi yönetim ve yerel yönetimin sınırlılıklarını ve üstünlüklerini dikkate alarak dengeleyici bir şekilde oluşturulabilir. Aynı zamanda okulların kaynak yönetiminin etkililiğini sağlamak amacıyla giderlerin azaltılması konusunda tüm üyelere duyarlılık kazandırılabilir.

2.Okul yöneticileri eğitim finansmanı politikalarının uygulama sorunlarını okul temelli ve Bakanlık temelli sorunlar olarak belirtmeleri nedeniyle oluşturulacak yeni eğitim finansmanı politikalarının en önemli belirleyicisi olarak MEB'in okulların gereksinimlerini rasyonel olarak dikkate alması, üst yönetimlerin sistemi iyi bir şekilde analiz etmesi ve aynı zamanda toplumun farklı kesimlerinden okul aile birliğinde görev alan ve okula mali kaynak yaratmaya çalışan paydaşlarının görüşlerinin alınması sonucunda planlanabilir. 
3.Okul yöneticileri okul kademelerine göre eğitim finansmanı politikalarının yansımalarının karşılaştırılması sonucu "ilkokul ve ortaokul kademelerini dezavantajı" olarak belirtmişlerdir. Bu doğrultuda bu kademelerde yaşanan sorunların çözümü açısından konsolide bütçeden daha fazla kaynak ayrılması önerilebilir. Okul yöneticileri finansman yönetimi konusunda okul kademesinin dezavantajları ile baş edebilmek için okullararası işbirliğini geliştirecek şekilde tüm paydaşların katılımını sağlayarak sorunlarını değerlendirmeye açabilir ve sistemini şeffaf hale getirebilir.

4.Okul yöneticileri eğitim finansmanı politikalarının uygulama sorunlarının nedenleri olarak "eğitim politikasının niteliği, bütçe yönetimi ve planlama eksikliği" ile mevcut karar mekanizmasını ve "veliden destek görememe" ile hizmet alanlarını belirttiklerinden eğitime erişim ve başarıda eşitsizlikleri azaltacak, iktisadi ve sosyal gelişmeye yol açabilecek kaliteli bir eğitim sunulmasını sağlayacak ve kamu tarafından gerçekleştirilen kişi başı eğitim harcamalarının bölgeler arasında eşit dağılmasını gerçekleştirebilecek eğitim finansmanı politikaları oluşturulabilir ve velilerin bu konuda farkındalık düzeyleri geliştirilebilir.

5.Okul yöneticilerinin eğitim finansmanı politikalarının sorunlarının çözümüne ilişkin görüşleri doğrultusunda okul üyeleri ve yöneticileri ile bakanlık yöneticilerinin eğitim finansmanı yönetimi konusunda yetkinlikleri güçlendirilebilir.

6.Kamunun eğitim harcamalarının bölge ve illere nasıl dağıldığını saptamayı sağlayacak kurumsal yapının oluşturulması gerekmektedir. Bu yapıdan sağlanacak bilgilere göre, dezavantajlı bölgelere öncelik verilerek kullanılması sağlanabilir.

7.Yerel ve ulusal düzlemde ayrılan finansal kaynakların nasıl dağıtıldığı ve okul başına nasıl yansıdığı incelenebilir.

\section{KAYNAKLAR}

Altuntaş, S. Y. (2005). İlköğretim okullarının finansman ihtiyaçlarını karşılama düzeyleri (Van ili örneği). Yayımlanmamış yüksek lisans tezi, Yüzüncü Yıl Üniversitesi Sosyal Bilimler Enstitüsü, Van

Aydın, M. (2000). Eğitim Yönetimi. Ankara: Hatiboğlu Basım ve Yayım.

Ak, T. (1997). Türk eğitim sisteminin ekonomik analizi. (Yayımlanmamış Yüksek Lisans Tezi), Eskişehir Anadolu Üniversitesi, Eskişehir.

Alpay, A.G. (2011). illköğretim okullarında finansman ile ilgili okul müdürlerinin görüsleri üzerine nitel bir araştırma.(Yayımlanmamış Yüksek Lisans Tezi). Yeditepe Üniversitesi Eğitim Bilimleri Enstitüsü Eğitim Yönetimi ve Denetimi Yüksek Lisans Programı. İstanbul.

Altunay, E. ve Ağaçdiken, Y. E. (2016). İlkokul ve ortaokul öğretmenlerinin eğitim politikasına ilişkin metaforlarının değerlendirilmesi. 12. Ulusal Eğitim Yönetimi Kongresi. 12-14 Mayıs 2016. İzmir

Bottoms, G.and Schmidt-Davis, J.(2010). The three essentials: improving schools requires district vision, district and state support, and principal leadership. The Texas Educational Excellence Project. The University of Texas - Pan American, University of Texas at Dallas, University of Kansas, University of Oklahoma, and the University of lowa.

Carnoy, M. (1995). Rates of return to education. In Carnoy, M. (Ed.) International encyclopedia of economics of education. (pp. 364-369). Oxford, UK: Elsevier. 
Davis, R.G. (1980). Issues and problems in the planning of education in developing countries. (Planning education for development, v.1). Cambridge, MA: Center for Studies in Education and Development, Harvard University.

Devrim, F. ve Tosuner, M. (1987). Türkiye'de eğitim hizmetlerinin finansmanında son gelişmeler. 3. Türkiye Eğitim Maliye Sempozyumu Bildiri Kitabı, 86-109. İstanbul

ERG (Eğitim Reformu Girişimi) (2009). Eğitimde eşitlik politika analizi ve öneriler. Türkiye'de Eğitimde Eşitliğin Geliştirilmesi için Verilere Dayalı Savunu" projesi. Açık Toplum Enstitüsü.İstanbul: ERG

Ergen, H. (2013). Türkiye'de eğitimde planlama yaklaşımları ve kullanılan eğitim göstergeleri. Mersin Üniversitesi Eğitim Fakültesi Dergisi, 9 (2), 151-167.

Güngör, G. ve Göksu, A. (2013). Türkiye'de eğitimin finansmanı ve ülkelerarası bir karşılaştırma. Celal Bayar Üniversitesi i.i.B.F. Yönetim ve Ekonomi. 20 (1), 59-72.

Gümüşeli, A. İ. ve Hacıfazlıoğlu, Ö. (2009). Globalization and conflict management in schools. Cyproit Journal of Educational Sciences, 4,183-198.

Hoşgörür, V. ve Arslan, İ. (2014). Okul örgütünün finansal kaynaklarının yönetimi sorunu (Yatağan İlçesi Örneği).Trakya Üniversitesi Eğitim Fakültesi Dergisi, 4 (1), 91-1022

Hesapçıŏlu, M. (1994). İnsan kaynakları yönetimi ve ekonomisi. İstanbul: Beta Basım Yayım Dağıtım A.Ş.

Karakul, A.K. (2014). İran ve Türkiye'de eğitim finansmanının karşılaştırılması. Mehmet Akif Ersoy Üniversitesi Eğitim Fakültesi Dergisi, 31, 67-87

Kavak, Y. ve Ekinci, C. E (1994). Eğitimin Finansmanı sorunu ve maliyetlerin azaltılmasına ilişkin alternatif stratejiler. Hacettepe Üniversitesi Eğitim Fakültesi Dergisi. 10, 65-72

Kavak, Y. Ekinci, E. ve Gökçe, F. (1997). Ilköğretimde kaynak arayışları. Kuram ve Uygulamada Eğitim Yönetimi Dergisi. 3 (3), 309-320.

Kurul, N. (2012). Eğitim finansmanı. Gözden Geçirilmiş ve Genişletilmiş 2. Baskı. Ankara: Siyasal Kitabevi.

Kurul Tural, N. (2012). Eğitim finansmanı. Ankara: Anı Yayıncılık

Küçüker, E. (2010). Türkiye'de eğitim planlaması neyi hedefliyor? International Conference on New Trends in Education and Their Implications 11-13 November, 2010 Antalya-Turkey ISBN: 9786053641049

Menteşe, S., Üstün, A., Gökdelen, A. (2012). İlköğretim okulu yöneticilerinin okulun parasal kaynaklarını yönetme yeterlikleri (Ordu Illi örneği). Hitit üniversitesi Sosyal Bilimler Enstitüsü Dergisi. 5 (2), 43.

OECD (2013). Eğitim politikası genel görünümü: Türkiye. Daha İyi Yaşamlar İçin Daha İyi Politikalar. www.oecd.org/edu.

Özdemir, M. (2011). Eğitim yönetimi politikalarındaki dönüşümün yoksulluk üzerindeki olası etkileri. GÜ, Gazi Eğitim Fakültesi Dergisi. 31 (3), 707-725

Özen, Y., Gül, A. ve Gülaçtı, F. (2007). Demokratik eğitim politikası (eleştirel bir yaklaşım). Erzincan Eğitim Fakültesi Dergisi. 9 (2), 111-130 
Özer, N., Demirtaş, H. ve Ateş, F. (2015). Okulların mali durumlarına ve bütçe yönetiminde yaşanan sorunlara ilişkin müdür görüşleri. e-Uluslararası Eğitim Araştırmaları Dergisi. 6 (1), 17-39

Özmen, F. ve Yalçın, H. (2011). Devlet ilköğretim okullarının mali açıdan desteklenmesinde velileri bağış yapmaktan uzak tutan nedenler. Fırat Üniversitesi Sosyal Bilimler Dergisi. 21 (1), 57-76, Elazı̆̆.

Saklan, E. ve Erginer, A (2016). Türkiye'de okul öncesi eğitime ilişkin politika ve finansman uygulamaları. Nevşehir Hacı Bektaş Veli Üniversitesi, Sosyal Bilimler Enstitüsü Dergisi. 6 (2), 15-44.

Şimşek, H. (2016). Eğitim gündelik siyasete kurban edilmemeli. 08.12.2016. https://tr.sputniknews.com/.../201612081026210102-hasan-simsek-.

Şişman, M. (2014). Türk eğitim sistemi ve okul yönetimi. 8. Baskı. Ankara: Pegem A Akademi

Walker, M. B.L. ve Morton, M. T., (2011). Budget cuts create problems in schools according to texas principals. Learning-Centered Leadershıp Program.

Tilak, J.B.G. (2002). Education and poverty. Journal of Human Development, 3 (2), 191-207.

Tilak, J. B. G. (1977) Approaches to educatıonal planning and their applications-in India. Reprinted from Indian Economic Journal, 24 (3).

Tonbul, Y. (2016). Eğitimin ekonomisi. Eğitbilim: Pedandragoji içinde. (Editör: Erdal Toprakçı). Ankara: Ütopya Yayınevi.

TUik (Türkiye İstatistik Kurumu) (2016). Gelir ve yaşam koşulları araştırması-2015 http://www.tuik.gov.tr/PreHaberBultenleri.do?id=21584

Tuzcu, G. (2004). Eğitimin finansman gerekleri ve boyutları. Milli Eğitim Dergisi. 163. http://yayim.meb.gov.tr/dergiler/163/tuzcu.htm

Türnüklü, A. (2001). Eğitimbilim alanında aynı araştırma sorusunu yanıtlamak için farklı araştırma tekniklerinin birlikte kullanılması, Eğitim ve Bilim, 26 (120), 8-13.

Vila, L. E. (2005). The outcomes of investment in education and people's well-being. European Journal of Education, 40, 3-11

Woodhall, M (1974). The investment approach to educational planning. No. 32 The Fundamentals of Educational Planning: Lecture-Discussion Series. Unesco: Internatıonal Institute For Educational Planning. Paris. http://unesdoc.unesco.org/images/0006/000692/069263eo.pdf

Yapıcı, M. (2006). Eğitim politikaları ve etkileri. Üniversite ve Toplum. 6 (2)

Yıldırım, A. ve Şimşek, H. (2013). Sosyal bilimlerde nitel araştırma yöntemleri. Genişletilmiş 9. Baskı) Ankara: Seçkin Yayınları.

Yıldırım, A. ve Şimşek, H. (2004). Sosyal bilimlerde nitel araştırma yöntemleri (4. Baskı) Ankara: Seçkin Yayınları.

Yolcu, H. (2007). Türkiye'de ilköğretim finansmanının değerlendirilmesi. (Yayımlanmamış doktora tezi). Ankara Üniversitesi Eğitim Bilimleri Enstitüsü, Ankara. 


\section{SUMMARY}

When literature about education financing policies is examined the standards of education financing are seen one of indicators of human developments of countries. In compared with developed countries in Turkey these standards in schools are far from meeting the expectations. In this context usually education policies and particularly in the field of education financing policies the increasing of results and resources of scientific studies can be presented an opportunity for developing a foresight both politicians and practitioners. Therefore in this study, we hope to contribute to the education field thanks to investigating school administrators' opinions related to education financing policies.

In this research in order to investigation detailed the school administrators' views about the education financing policies, the phenomenological research design among qualitative method researches was conducted. The phenomenological research design is a research design included that researcher who sees some people and groups as a data resources, who some people and groups experienced some phenomenon and this phenomenon to find out and reflect, investigates the phenomenon that researcher wants to have in-depth and detailed understanding although he/she is aware. The sample of this research composed of 30 school administrators from primary- secondary and high school administrators. In this research maximum variation sampling technique was used as one of the purposive sampling techniques. In order to ensure to show the maximum variation of sampling participants determined composed of school administrators selected from education institutions at the three degree (primary, secondary and high school-high vocational school). Since in this research the phenomenological research design among qualitative method researches was selected, for collecting the data it was used the quasi-structured interview technique and form. Descriptive and content analysis techniques were used to analyze the data of the study.

According to the findings of this research, the school administrators' views about the education financing policies were collected on the topics as a school incomes and school expenses. Although in the category of school incomes was found that financing resources were limited, in the category of school expenses was found that expenses were diversified and it was shown that school administrators supported that school expenses must be paid mostly on basis of public resources. The school administrators thought that the ministry was insensitive to the demands of school administrators in terms of meeting the expense of their schools.

The school administrators defined the implementation problems of the education financing policies due to school-based and Ministry-based problems. As an implementation problems of educational financing policies among school-based problems were specified the topics such as the expenses about personal, problems related to budget management and not payment education-training fee; among Ministry-based problems were specified the topics such as the limited of the budget amount and the problems of professionalization on the budget management.

When school administrators compared the reflections of education financing policies according to school degrees, it was found three categories such as the primary school financing, secondary financing, and high school categories. According to school degrees, primary and secondary school levels are disadvantageous about education financing.

The school administrators thought that the reasons of implementations problems of education financing policies were the topics of the quality of education financing policies, budget management, lack of planning and lack of support from public or family. 
The school administrators' opinions about the solutions of problems of the education financing policies collected on the topics such as a new education financing policies, management structure, development of knowledge about finance expertise and usage of resource

In line with research problems, the school administrators'opinions about the education financing policies were evaluated. It was found that school administrators'opinions contained the criticisms and solutions about the education financing policies based on lacking of resources examined in their schools. The competence of school members, administrators and ministry officials on education financing management needs to be strengthened.

Because the school administrators thought that the ministry was insensitive to the demands of school administrators in terms of meeting the expense of their schools, it should be solved the lack of finance of schools. The new education financing policies should be created in a balanced way taking into account of limitations and advantages of the central government and local government.

Since the school administrators defined the implementation problems of the education financing policies due to school-based and Ministry-based problems, the new education financing policies to be created should be planned a result of rationally taking into account of the requirements of schools, analyzing of the system by top managements in a good way and at the same time to been taken societies opinions.

According to school degrees as a result of compared the school administrators' opinions about the reflections of education financing policies, they were said that the primary school and secondary schools were disadvantages. Therefore the government should be allocated more resources from general budget to education system for being provided with resources to school degrees. 